УДК 902/904

https://doi.org/10.24852/2587-6112.2021.2.62.81

\title{
ПРЯСЛИЦА ЗУЕВОКЛЮЧЕВСКОГО І ГОРОДИЩА В НИЖНЕМ ПРИКАМЬЕ
}

\author{
(C) 2021 г. Е.М. Черных
}

В статье рассматривается одна из наиболее представительных и значимых категорий предметов, встречающихся в культурных слоях поселений Волго-Камья - пряслица. С Зуевоключевского І городища - одного из крупнейших городищ Прикамья - происходит едва ли на самая обширная коллекция пряслиц раннего железного века. Трактовка пряслиц как артефактов культуры ткачества в архаических обществах, начиная с эпохи неолита, уже не столь однозначна. Тем актуальнее обращение к каждой целостной коллекции находок. Анализируются материал, форма, декор пряслиц, происходящих из стратифицированных слоев ананьинского и пьяноборского времени; их горизонтальное и вертикальное распределение в культурных напластованиях и объектах; оценивается возможность пряслиц как культурно-хронологических индикаторов.

Ключевые слова: археология, ранний железный век, Прикамье, городище, пряслица, морфология, использование.

\section{SPINNING WHEEL FROM ZUEVOKLYUCHEVSKOE I HILLFORT IN THE LOWER KAMA REGION}

\section{E.M. Chernykh}

The paper addresses one of the most representative and significant categories of items discovered in the cultural layers of the Volga-Kama settlements - a spinning wheel. Zuevoklyuchevskoe I hillfort - one of the largest fortified settlements of the Kama Region - is the origin of arguably the most extensive collection of spinning wheels of the Early Iron Age. The interpretation of spinning wheels as artifacts of the weaving culture in archaic societies, starting from the Neolithic period, is no longer unambiguous. Hence the more relevant references to each complete collection of finds. The material, shape and decoration of the spindle wheels originating from the stratified layers of the Ananyino and Piany Bor period are analyzed, and their horizontal and vertical distribution in the cultural layers and sites is assessed, along with the possibility of considering spinning wheels as cultural and chronological indicators.

Keywords: archaeology, Early Iron Age, Kama Region, hillfort, spinning wheels, morphology, application.

Зуевоключевское I городище - самое крупное из известных на сегодня ананьинских городищ в Среднем и Нижнем Прикамье (площадь его составляет более 3 га). Честь открытия памятника принадлежит А.А. Спицыну (1893, c. 120-121). Сегодня в распоряжении ученых имеется довольно детальная информация не только о стратиграфии этого памятника, но и планировке собственно городища раннего железного века, материальной культуре его обитателей, этапах функционирования, ближайшей округе (Ашихмина, 2014; Ашихмина, Генинг, 1986, с. 123-137; Голдина, 1995, c. 34-48; Голдина, Черных, 2011, с. 60-63; Черных, 2004, с. 113-131; Черных, 2009, с. 76-97; Черных, 2012, с. 113-123; Черных, 2013; Черных, 2014, с. 153-165; Митряков, Черных, 2017, с. 17-32; Черных, 2018, с. 267-290; Черных, Колобова, 2006, с. 145-151; Черных, Цыгвинцева, 2006, с. 180-186).

В 1912 г. городище осматривалось сотрудником Сарапульского земского музея Л.А.
Беркутовым (1914, с. 67-68), снявшим его первый глазомерный план. В 1970 г. первые раскопки на городище проведены Р.Д. Голдиной, в дальнейшем продолжены В.Ф. Генингом и Л.И. Ашихминой (всего было заложено 14 раскопов, общей площадью почти 5 тыс. кв. М).

В 1997 г., после длительного перерыва, раскопки на городище были возобновлены E.M. Черных и продолжались в течение 9 лет. Одновременно проводились исследования на близлежащих селищах, давшие основания для рассмотрения особенностей расселения в границах отдельного микрорегиона рубежа эр (Карпушкина, Черных, 2007). На Зуевоключевском II селище был заложен раскоп площадью 130 кв. м, включавший также траншею, разрезавшую ров в напольной части городища (Вязников и др., 2001, с. 179-181). Среди находок на селище - фрагменты лепной посуды как ананьинского, так и пьяноборского времени, артефакты бытового и производственно- 
го класса (пряслице, тигли, шлаки, сплески металла, абразивы). На Зуевоключевском IV селище раскопом 54 кв. м изучены остатки наземной постройки и отдельные объекты ананьинско-чегандинского времени. С регулярно распахиваемой площадки селища был собран также керамический материал, датируемый финалом бронзового века (маклашеевская культура) и металлические украшения чегандинской культуры первых веков н. э. Одновременно открыто Зуевоключевское VIII селище (Голдина, Черных, 2011, с. 37). В глубине балки Гремячий ключ, на ее левом берегу, изучено рекогносцировочным раскопом (72 кв. м) Зуевоключевское III (Хижняковское) городище (Карпушкина, 2005; Голдина, Черных, 2011, с. 64-64).

В исследованиях городища 1998-2000 гг. был реализован комплексный подход, с участием сотрудников ФТИ УрО РАН (И.В. Журбин, В.П. Зверев, А.В. Зелинский; Журбин, 2004), геоморфолога А.В. Сергеева (кафедра физической географии УдГУ), почвоведа А.В. Туганаева (лаборатория почвенной экологии УдГУ), биолога О.А. Капитоновой (УдГУ), археозоолога О.Г. Богаткиной (Национальный музей РТ, г. Казань). Одновременно, были возобновлены раскопки ананьинского Зуевского (Зуевоключевского I) могильника, на площадке которого С.Е. Перевощиковым изучены 10 погребений раннего железного века и 7 погребений XVI-XVII вв. (Перевощиков, 2000, с. 250-251; Голдина, Черных, 2011, с. 86-89).

Работы на объектах Зуевоключевского микрорайона продолжались непрерывно до 2005 г. Общая изученная раскопками площадь на территории городища достигла 8000 кв. м.

Зуевоключевское I городище представляет собой многослойный и многокомпонентный памятник, на площадке которого в ходе раскопок были выявлены и изучены Зуевоключевская І стоянка позднего бронзового века (луговская АК), погребения эпохи бронзы, раннего железного века и нового времени (Зуевоключевской II могильник), неукрепленное поселение раннеананьинской культуры и остатки усадьбы XVI-XVII вв. (Зуевоключевское III поселение), городищенский слой ананьинскопьяноборского времени. Мощность культурных напластований на городище варьируется от 0,1 до 2,0 м. Многолетними исследованиями в них изучены жилые, хозяйственные, производственные, фортификационные сооружения, собраны представительные коллекции предметов быта, орудий труда, украшений из черного и цветного металлов, стекла, кости, камня, массовые керамические коллекции эпохи бронзы - раннего железного века.

Раннеананьинская керамика, встреченная локально (3 жилища и несколько ям), принадлежит догородищенскому этапу и характеризуется двумя культурными традициями - постмаклашеевской и ранней сложношнуровой.

Очевидно, в конце $\mathrm{V}$ в. до н.э. в западной части мысовой площадки насыпается вал, за ним следует глубокий ров, а в 12 м имелся еще один, до настоящего времени не сохранившийся. Новому периоду в истории поселения соответствуют мощные зольно-пепельные рыхлые напластования с остатками жилых и хозяйственных сооружений. В планировке поселка угадывается регулярность: рядовая застройка домов, довольно однотипные наземные постройки, выделение функциональных зон, связанных с производственной и культовой деятельностью. Используется интенсивно округа городища. Конец ананьинской эпохи (IV-III вв. до н. э.) характеризовался общими для Прикамья изменениями в облике керамики (практически исчезает из декора шнур), расширением сети открытых поселений, строительством нового городища (Зуевоключевское III). На старом городище в южной части формируется святилище с центральной культовой постройкой. В следующую пьяноборскую эпоху городище по-прежнему существует как укрепленный центр, но фортификации на нем обновлялись лишь однажды и скорее всего уже не представляли серьезной мощи. К тому же верхний слой городища наиболее пострадал от деятельности человека и судить о характере застройки в этот период можно весьма избирательно. Необходимо также заметить, что датирующие находки из верхних напластований охватывают широкий временной диапазон - II в. до н.э. - V-VI вв. н.э., то есть жизнь на городище продолжалась как в чегандинское, так и в мазунинское время.

Материалы, полученные в ходе исследований памятника (более 20000 фрагментов керамики, более 1000 индивидуальных находок), оказались в различных музейных собраниях: Государственном Эрмитаже (коллекция № 609), в Музее истории и культуры Среднего Прикамья г. Сарапула (коллекция Л.А. Беркутова № 4100), Национальном музее УР им. Кузебая Герда (коллекции №№ 62, 95, 478, 522); Удмуртском госуниверситете (коллекции №oㅡ 619, 1362, 1476, 1914, 2024, 2075, 


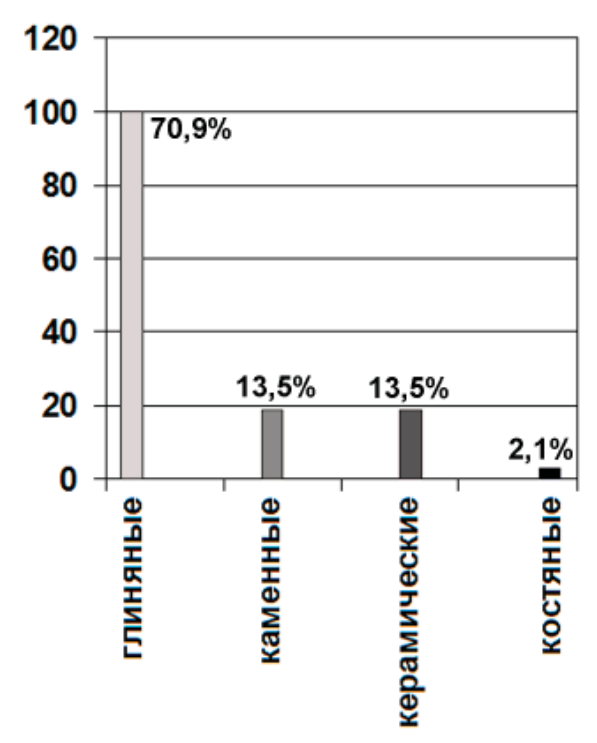

Рис. 1. Зуевоключевское I городище. Распределение пряслиц по материалу.

Fig. 1. Zuevoklyuchevskoe I hillfort.

Distribution of the spinning wheels by material

2120, 2140, 2147, 2163); Институте истории и археологии УрО РАН (г. Екатеринбург; археозоологическая коллекция).

В данной статье рассматривается коллекция пряслиц периода раннего железного века, общее количество которых составляет более 140 единиц. Под пряслицем в археологии, как правило, понимается небольшое колесико преимущественно круглой в горизонтальном сечении формы с отверстием в центре. Пряслица традиционно рассматриваются как материальные свидетельства наличия прядения и ткачества в обществах прошлого, начиная с эпохи неолита. Вместе с тем в научной литературе можно найти немало фактов их использования в качестве грузиков для сетей, предметов товарно-денежного обмена, пуговиц, предметов ритуальных практик.

Систематизация зуевоключевских пряслиц была выполнена по различным основаниям, включающим такие признаки как материал, форма, размеры, декор.

По материалу выделены 4 группы предметов: керамика (диски изготавливались из стенок керамических сосудов), глина, камень, кость. Абсолютно преобладают в коллекции диски, вылепленные из глины (рис. 1), но степень их сохранности наименьшая (рис. 2). По форме сечения выделены типы: I - полусферическое, II - трапециевидное, III - прямоугольное; IV - битрапециевидное; V - овальное; VI - прямоугольно-трапециевидное. По особенностям приканальных площадок - подтипы: A - обе приканальные площадки ровные, плоские; D - выпукло-вогнутые; Е - обе поверхности выпуклые. Варианты выделены по форме края диска - гурта (всего 6): прямой, округлый, кососрезанный, асимметричный, с изломом, желобчатый.

Классификаџия по форме выполнена для 141 диска.

Группа 1 - глиняные (100 экз.; 71\%). Эти маховички вылеплены из глины, приготовленной зачастую по тем же рецептам, что и сосуды. Форма определена у 98 экземпляров.

Тип 1 - полусферические (26 экз.; рис. 3: 2, $3,7 ; 4: 2: 6,7 ; 6: 4,7)$. Все относятся к подтипу $\mathrm{C}$ - одна поверхность прямая, другая выпуклая. Край у всех дисков округлый.

Тип II - сечение трапециевидное (рис. 5: 7). Единственное изделие данного типа имело плоскую верхнюю площадку и слегка вогнутую - нижнюю (подтип В), асимметричные края. Последняя характеристика диска, с учетом того, что отверстия канала также не равноценны, позволяет рассматривать изделие как пряслице условно.

Тип III - прямоугольные (58 экз.; рис. 3: 1, 4, 5, 6, 8-10; 4: 2-5, 8, 10; 5: 8; 6: 1, 3, 5, 6, 8; 7: 3, 6-9). Диски данного типа наиболее вариативны по форме приканальных площадок: подтип А - обе площадки плоские; подтип В с плоской верхней и вогнутой нижней площадками; C - с плоской и выпуклой площадками; Д - с выпукло-вогнутыми поверхностями; Е - обе площадки слегка выпуклые. Наиболее распространены плоские и сглажено-округлые края дисков.

Тип IV - битрапециевидные (4 экз.; рис. 7: $4,5)$. Имеют плоские приканальные площадки и край с изломом/ребром.

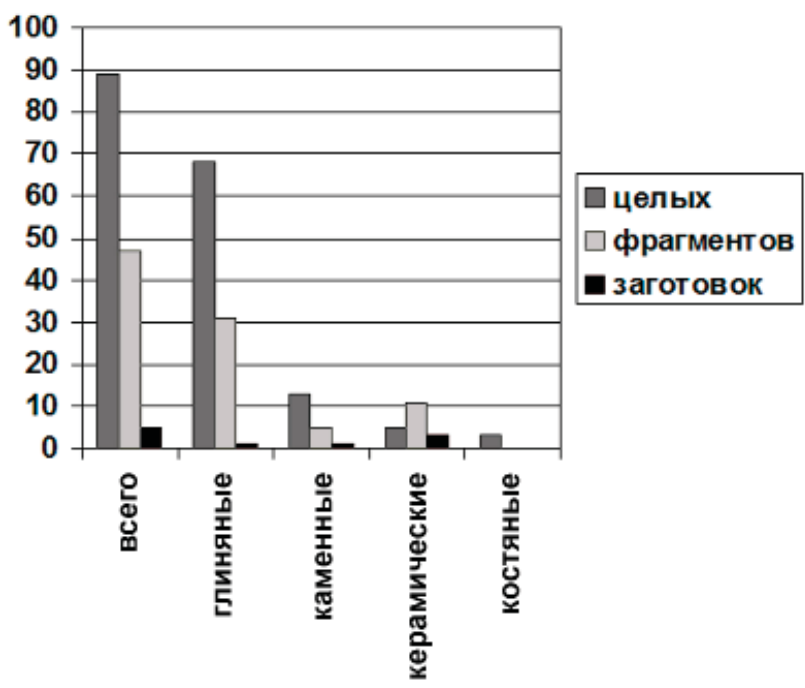

Рис. 2. Зуевоключевское I городище. Соотношение целых форм пряслиц, их заготовок и фрагментов

Fig. 2. Zuevoklyuchevskoe I hillfort. Ratio of the whole shapes of spinning wheels, their blanks and fragments 

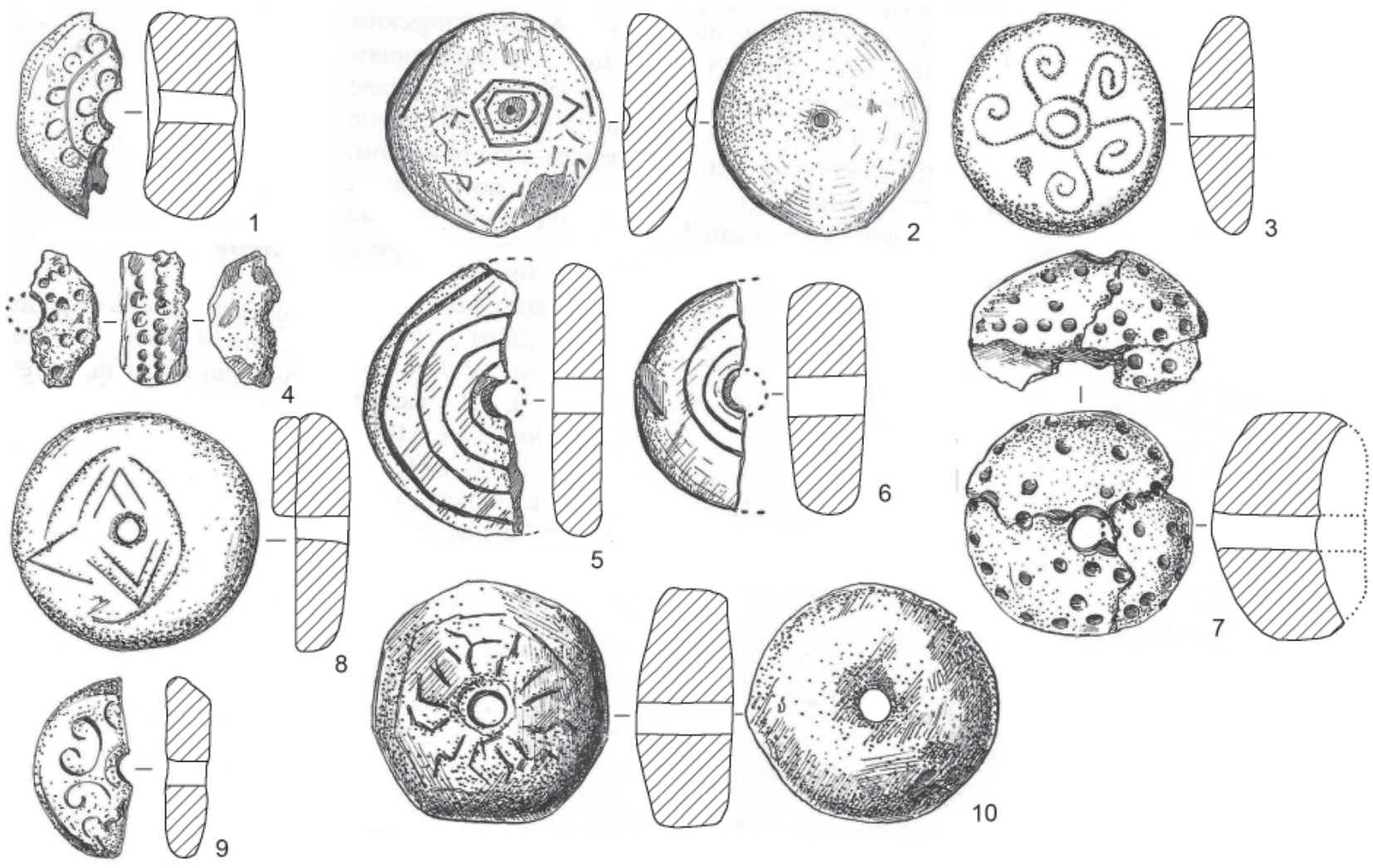

Рис. 3. Зуевоключевское I городище. Пряслица из слоя и объектов ананьинского времени: 1, 2, 4-5, 7, 10 - глина; 3, 6, 8, 9 - камень. Художник Н.Ф. Шишкина

Fig. 3. Zuevoklyuchevskoe I hillfort. Spinning wheel from the layer and items of the Ananyino period: 1, 2, 4-5, 7, 10 - clay; 3, 6, 8, 9 - stone. Artist N. F. Shishkina
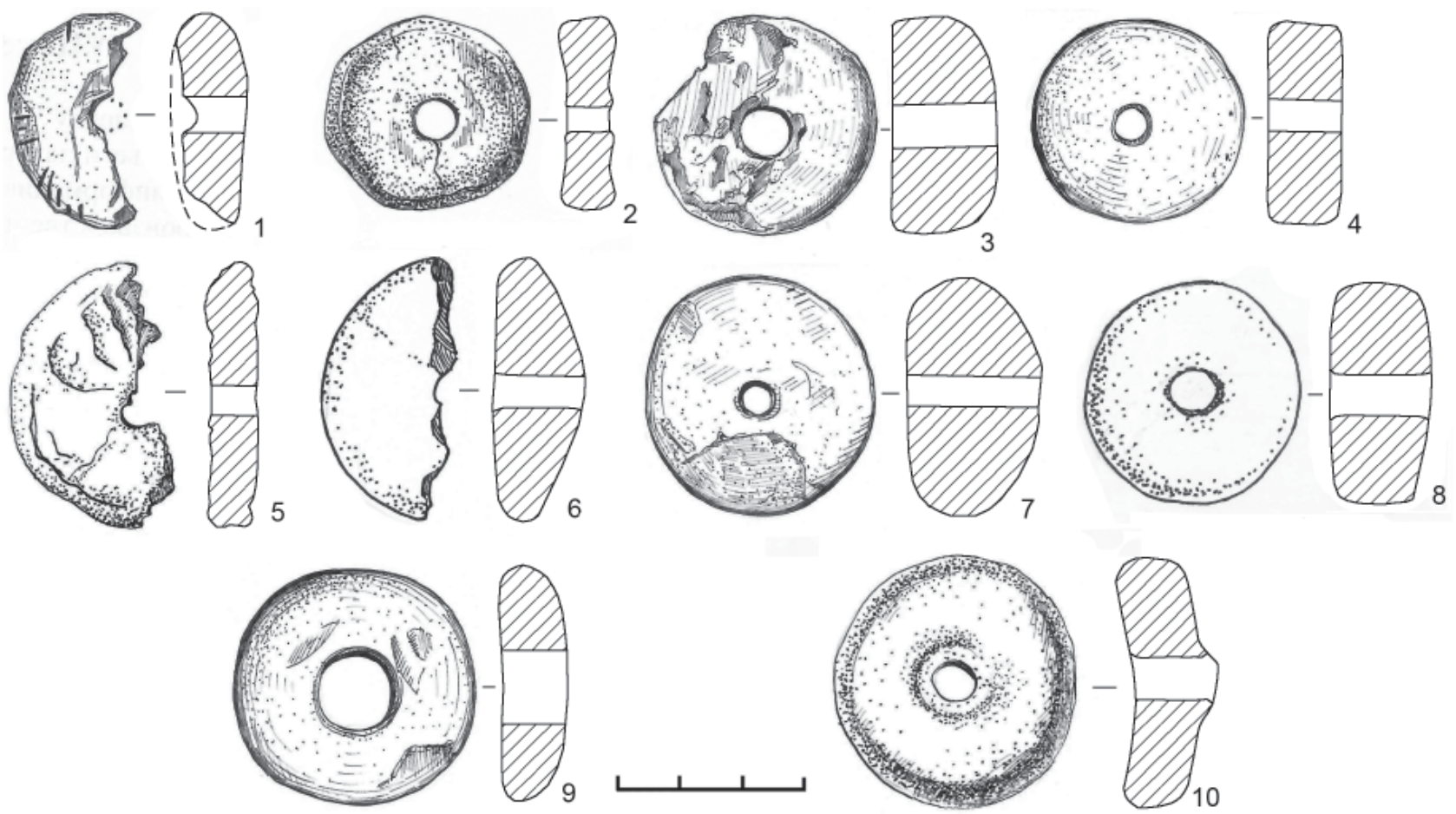

Рис. 4. Зуевоключевское I городище. Пряслица из слоя и объектов ананьинского времени: 5 - камень; остальные - глина. Художник Н.Ф. Шишкина

Fig. 4. Zuevoklyuchevskoe I hillfort. Spinning wheel from the layer and items of the Ananyino period: 5 stone; others - clay. Artist N. F. Shishkina 


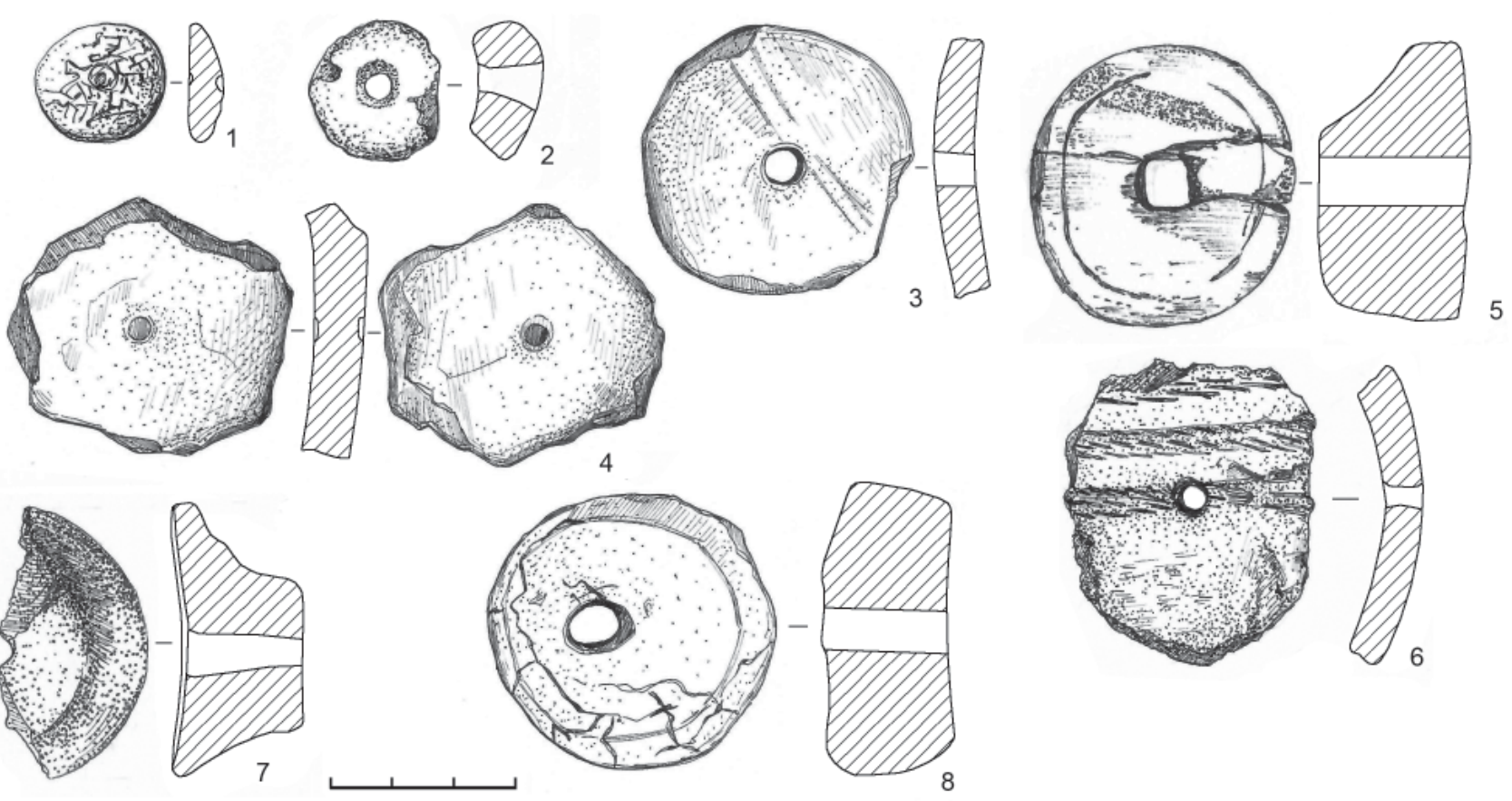

Рис. 5. Зуевоключевское I городище. Пряслица и предметы с отверстиями из слоя и объектов ананьинского времени: 1 - камень; 2, 5 - кость; 3, 4, 6 - керамика; 7, 8 - глина. Художник Н.Ф. Шишкина.

Fig. 5. Zuevoklyuchevskoe I hillfort. Spinning wheel and items with holes from the layer and items of the Ananyino period: 1 - stone; 2, 5 - bone; 3, 4, 6- ceramics; 7, 8- clay. Artist N. F. Shishkina

Тип V - овальные (8 экз.; рис. 4: 1, 9; 6: 2). $\mathrm{У}$ всех изделий слегка выпуклые приканальные площадки (подтип Е) и округлый край. эКз.)

Тип VI - прямоугольно-трапециевидные (1

Группа 2 - керамические пряслица (рис. 5: $3,4,6)$, выполнены из стенок сосудов (19 экз.; в большей части - это заготовки, т.е. диски с незавершенным отверстием или необработанным краем). Составляют 13,5\% всей выборки. Характерно, что одно пряслице изготовлено из стенки типичного ананьинского сосуда, украшенного веревочным/шнуровым орнаментом. Все диски в силу особенностей их изготовления принадлежат к типу III (с прямоугольным сечением). Выделяются два подтипа, когда обе приканальные площадки прямые, либо одна выпуклая, другая вогнутая.

Подтип А с прямыми площадками представлен пятью изделиями, у трех из которых края прямые, у двух - округленные. Остальные принадлежат к подтипу D - с выпукловогнутыми площадками (14 экз.). По форме края зафиксированы 4 варианта - с прямым, кососрезанным, округлым, асимметричными краями, что объясняется незавершенностью обработки изделия, либо издержками домашнего изготовления таких дисков, не особо тщательно подвергавшихся дополнительной отделке.

Группа 3 - каменные (19 экз.; 13,5\%). Классификации по форме поддаются 14 дисков.
Тип I - полусферические (2 экз.; рис. 3: 3; 5: 1). Оба экземпляра составляют подтип С - с выпукло-вогнутыми приканальными площадками и округлым краем.

Тип II - трапециевидные (2 экз.; рис. 7: 8) типа A - с прямыми приканальными площадками.

Тип III - прямоугольные (10 экз.; рис. $3: 6,8,9 ; 4: 5 ; 7: 6)$. Преобладают пряслица подтипа А с плоскими прямыми приканальными площадками и плоским краем. 2 диска принадлежат к редкому подтипу D - c выпукло-вогнутыми приканальными площадками и сглаженным ребром по краю.

Группа 4 - костяные (3 экз.; 2\% выборки)

Тип I - полусферическое (1 экз.; рис. 7: 2), изготовленное из суставной кости животного.

Тип III - с прямоугольным сечением (2 экз.). Одно из пряслиц было вырезано из плоской кости животного, другое из головки суставной кости (рис. 5: 2). Еще один предмет в коллекции был в полевых условиях учтен как пряслице, выточенное из крупной кости животного (рис. 5: 5), но таковым, по всей видимости, не являлся. Изделие имело довольно крупные размеры и сквозное отверстие прямоугольной формы, к тому же не центрированное, что отнюдь не способствовало сбалансированному вращению.

Размеры дисков рассмотрены по выделенным группам. 
Среди керамических дисков в целом наблюдается единообразие: величина дисков в среднем 4,5 см. Наибольшей величиной - 5,5 см - отличаются пряслица подтипа D. Диаметр центрального отверстия у дисков невелик - 0,4-0,6 см, как и толщина 0,6-0,8 см. Керамические диски просты в изготовлении, недостатка в подручном материале не было, но отсутствие у значительной части изделий правильной круглой формы заставляет задуматься - насколько в действительности они могли служить грузиками-утяжелителями для веретен. Вероятно, что показывает эксперимент, могли использоваться как приспособления для ссучивания шерстяных нитей (Фоломеев, Чернай, 1980, с. 49-50).

Глиняные пряслица имеют наибольший диапазон по показателям диаметра и толщины. Диаметр изделия варьируется от 2,8 до 6,0 см. Диаметр центрального отверстия - от 0,4 до 1,6 см, но наибольшая частота приходится на показатель 0,6 см. Для наиболее представительного типа глиняных пряслиц (имевших прямоугольное сечение) наблюдаются различия в метрике при сопоставлении вариантов изделий (по форме края/ребра). Так, пряслица с округлым краем имеют диаметр 2,6-5,4 см, диаметр отверстия 0,4-1,5 см, толщину 0,7-2,8 см, тогда как пряслица с плоским краем диаметр 3,2-5,0 см, диаметр отверстия 0,4-1,0 см, толщину 0,5-1,3 cм.
Наибольшая вариативность по метрическим признакам наблюдается у пряслиц с полусферическим сечением: диаметр их дисков варьируется от 2,7 см до 4,4 см, диаметр отверстия - в среднем 0,5 см, значителен диапазон толщины: 1,3-2,5 см.

Столь существенные метрические различия в этой группе пряслиц, вероятнее всего, следует рассматривать в контексте их длительного бытования, различного назначения, а также смены культурных новаций в обществе (например, изменение диаметра центрального отверстия, безусловно, следует за изменением веретена, качества пряжи и т.п.).

Каменные пряслица имеют диаметр дисков 2,1-5,4 см (в среднем 3,8 см), диаметр центральных отверстий в среднем - 0,7 cм. Диапазон толщины от 0,8 до 2,0 см. Толщина в основном не превышает 1 см, средний показатель ее 1,1 см - самый низкий в сравнении с дисками других отделов.

Костяные диски невелики по размерам. Диаметр в среднем 2,5 см, центрального отверстия - 1 см. По толщине диски не превышают 0,6 см. Есть крупный диск, диаметром 4,5 см и диаметром центрального отверстия 2,5 cм, высотой 2,4 см (рис. 5: 5), но, как уже сказано выше, скорее всего, к пряслицам не относится. В силу легкости и трудности балансировки такие диски, вероятно, использовались с другим назначением.

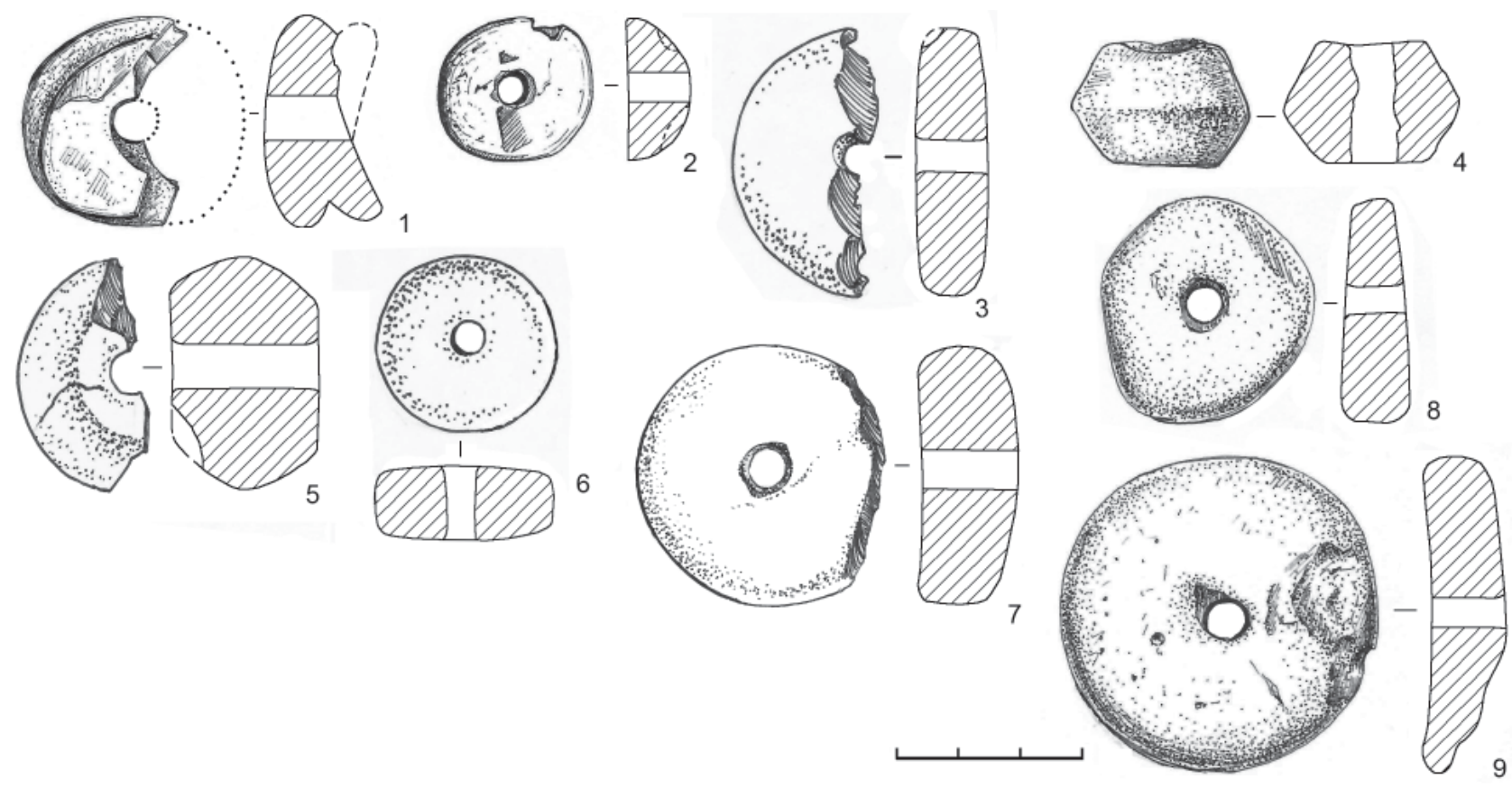

Рис. 6. Зуевоключевское I городище. Пряслица из слоя разрушения $(1,2)$ и пьяноборских объектов: 1, 3-5, 7, 9 - глина; 2 - кость; 6, 8 - камень. Художник Н.Ф. Шишкина.

Fig. 6. Zuevoklyuchevskoe I hillfort. Spinning wheel from the destruction layer $(1,2)$ and Pyany Bor items: 1, 3-5, 7, 9 - clay; 2 - bone; 6, 8 - stone. Artist N. F. Shishkina 
Таким образом, как можно заметить, средняя толщина каменных пряслиц наименьшая среди всех четырех групп, а у глиняных наибольшая. Это, возможно, связано с большей вариативностью размеров глиняных пряслиц и, соответственно, их многофункциональностью.

Декор пряслии. Орнаментированных дисков в коллекции 26 экз. (18\%). В этой статистике не использованы керамический диск из сосуда, украшенного веревочным орнаментом (рис. 5: 6), а также три пряслица с прочерченными знаками (рис. 5: 1; 6: 6). У всех пряслиц, кроме двух глиняных, декорирована лишь одна сторона. На двух дисках орнамент (круглые вдавления) нанесен также по гурту (рис. 3: 4).

Каменных орнаментированных дисков $6(31,5 \%$ от всех каменных и $23 \%$ - от всех декорированных). Глиняных орнаментированных - 19 (19\% от всех глиняных и 73\% - от числа всех декорированных). Костяные и керамические пряслица - неорнаментированные. То есть, можно сказать, что степень орнаментированности каменных дисков выше почти вдвое.

В коллекции нет абсолютно идентичных пряслиц. Но, не смотря на индивидуальность, все узоры содержат близкий набор элементов. Пряслица Зуевоключевского городища украшены с использованием простых геометрических элементов - круги, треугольники, ромбы, спирали, прямые и ломаные линии, складывающихся в определенные композиции или мотивы (по сути, ключевые аспекты изобразительного языка). Хорошо известно, что в основе ананьинского изобразительного творчества лежали орнаментальный стиль, растительный код, либо язык звериных образов (Збруева, 1952, с. 136-146; Корепанов, Обыденнов, 2009, с. 213-215), теснейшим образом связанных как с повседневной жизнедеятельностью, так и сферой сакрального, священного. Синкретизм первобытного мышления, представлявший сложные переплетения реалистического и умозрительного иллюзорного начал, оказывал решающее воздействие на характер художественного творчества. Эффективность многообразной хозяйственной деятельности у ананьинцев зависела от природных циклов, смерти и возрождения природного мира и места в нем самого человека. Отсюда - следы продуцирующей магии, промысловых/охотничьих и, возможно, шаманских культов (Збруева, 1952, с. 131-135; Ашихмина, 1992; Марков, 1994, с. 76).
Основу большинства композиций на зуевоключевских дисках составляют растительногеометрические орнаменты. В соответствии с ними выделены 3 типа композиции:

1. Концентрическая (13 экз., 10 глиняных, 3 - каменных). Изображения выполнены с помощью прямых и ломаных линий, треугольников (рис. 3: 5, 6; 6: 1, 3, 5, 7, 8).

2. Радиально-лучевая (9 экз., 6 глиняных и 3 каменных). Основу композиции составляют лучи, расходящиеся в разные стороны от центрального отверстия. В свою очередь, по стилю оформления луча выделяются секторальные композиции (когда лучи разбивают плоскость диска на несколько секторов) и композиции растительные - луч оформлен в виде крючка, лепестка, или завитка, т.н. S-овидные (рис. $3: 3,9,10 ; 4: 5$ ).

3. Спиралевидная (1 экз., глиняное; рис. 6: 8). Орнамент выполнен в виде спирали, свертывающейся по часовой стрелке (в направлении суточного движения Солнца).

Не вписывающиеся строго в эту схему диски, украшенные ямочными вдавлениями (4 экз.; рис. 3: 4, 7; 6: 1), тем не менее также подчинены идее круга - ямки хоть и размещены без определенного порядка, но органично вписаны в его пространство.

Как можно видеть из приведенных иллюстраций, указанные композиции зачастую взаимодополняют друг друга, да и принцип их использования един - композиционным центром, независимо от характера изображения, всегда остается центральное отверстие, вокруг которого раскручивается движение циклически повторяющихся фигур.

$\mathrm{O}$ семантике изображений на пряслицах прикамских культур раннего железного века, определяющим смысловым элементом в композиции которых является исходная форма предмета, а именно круг, написано достаточно (Ашихмина, 1992, с. 7; Сериков, 2005; Котов, 2010). Круг издревле считался символом бесконечности, законченности, высшего совершенства. Во временном плане идея круга находит еще большее воплощение. Она указывала на движение, динамику, цикличность процессов, временные категории - день, месяц, год. С кругом символизируется одна из самых вечных ориентационных примет космического порядка - Солнца. Любая окружность, круглая сферическая плоскость вызывали в первую очередь, солярные и шире - астральные ассоциации (Косарев, 2003, с. 211). Секторальная композиция также символизирует солнце, но не в дина- 


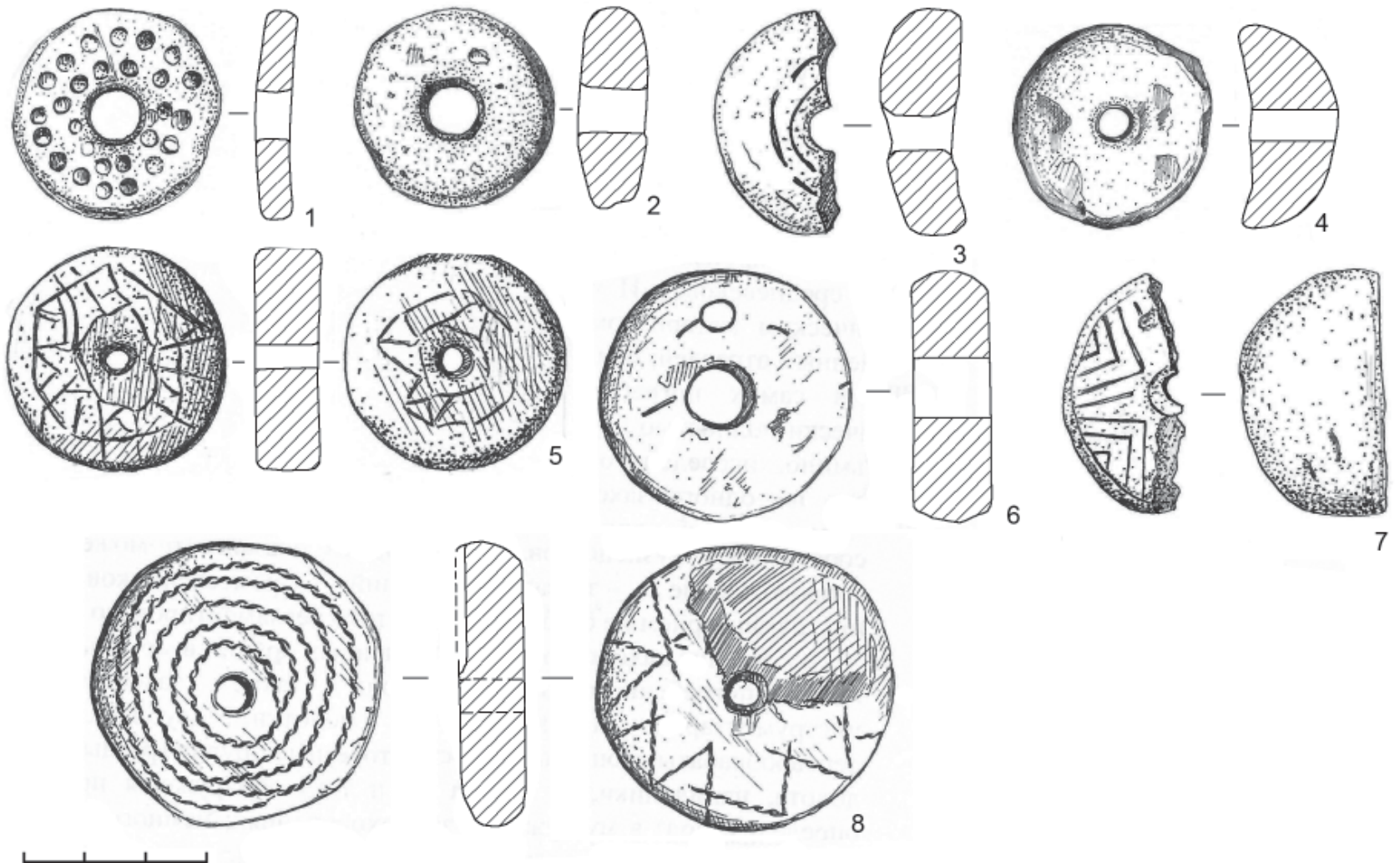

Рис. 7. Зуевоключевское I городище. Пряслица из разрушенных слоев: все - глина. Художник Н.Ф. Шишкина.

Fig. 7. Zuevoklyuchevskoe I hillfort. Spinning wheel from destruction layers: all - clay. Artist N. F. Shishkina

мике, а в статике. Динамику образу придает эффект вращения диска. $\partial о \kappa$

Стратиграфическое распределение нахо-

Характер почв на городище - легкие супеси и суглинки. Современная почва принадлежит к типу дерново-карбонатных и серых лесных; почвенные процессы в них протекают весьма активно. Установлено, что городищенский слой ананьинского времени (каменноложский и ныргындинский этапы АКИО, по Л.И. Ашихминой) хорошо стратифицирован, отличается мощностью, значительной степенью минерализованности, насыщенностью находками. Напластования распространены на площадке городища повсеместно и вмещают многочисленные строительные остатки в виде жилых, хозяйственных и производственных сооружений, распределяющихся в трех-четырех условных горизонтах (Черных, 2012, с. 114-115). Верхний культурный слой - чегандинско-мазунинский сохранился локальными участками, а также в жилищах и хозяйственных ямах. Он отличался от ананьинского слоя более темной окраской, мелкокомковатой (зернистой) структурой, значительными включениями обломков обожженной глины. От жилищ этого времени в слое сохранились фрагменты глиняных полов и массивных очажных площадок.
Стратиграфическое распределение находок производилось методом выделения групп по глубинам залегания с привязкой их к фоновым слоям. В результате выделены две основные группы пряслиц: ананьинская (пряслица происходят из слоев №o 3, 3a, 11 и 21, с глубиной залегания 30-60 см) и пьяноборская (слой № 2, глубина залегания (кроме ям) - до 30 см). Третья группа включает находки из разрушенных слоев (горизонт распашки), в которых могли оказаться как находки пьяноборского, так и ананьинского времени.

Достоверное положение пряслиц в слоях установлено только для 103 изделий из $141^{1}$ (рис. 8). Почти половина предметов из этого числа приходится на слои и объекты ананьинского времени (52 экз., $36,8 \%$ от общего количества пряслиц; рис. 3-5). Больше всего пряслиц, вылепленных из глины - 31, почти поровну каменных (9 экз.) и керамических (10 экз.), 2 диска изготовлены из кости. Для этой группы пряслиц наиболее характерны диски типа III с прямоугольным сечением (36 экз., 69 \%) подтипов А (11 экз.) и Д (14 экз.). У 9 дисков сечение полусферическое (тип I). Необычную форму - трапециевидную имеют один глиняный диск и один костяной (рис. 5: 5,7$)$. Они близки между собой и по параметрам, как представляется, имели близкое назначение. 


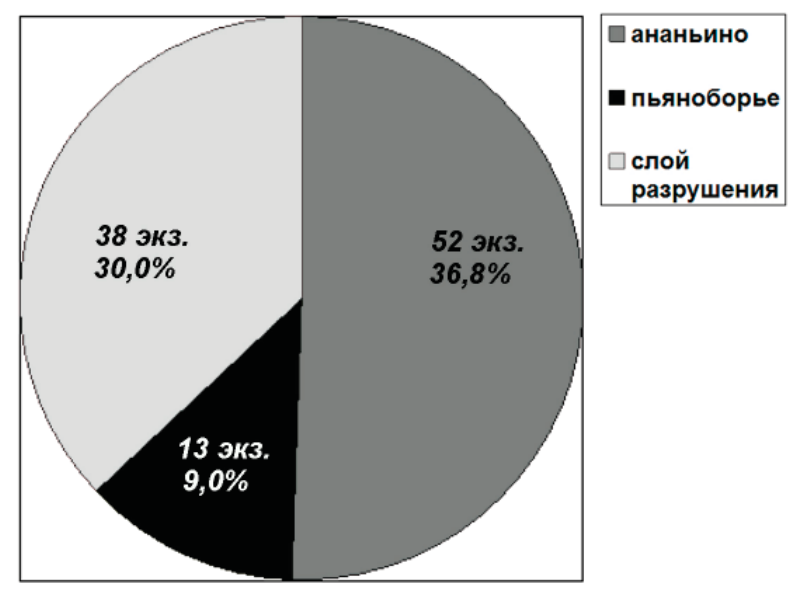

14 дисков, происходящих из ананьинских слоев, орнаментированы исключительно геометрическими узорами. На двух глиняных дисках декор имеет определенное сходство это округлые вдавления (рис. 3: 4, 7): в первом случае вдавления нанесены только по верхней выпуклой поверхности диска, хаотично; во втором - двумя ритмичными параллельными рядами по ребру и на одной из поверхностей в виде радиально расходящихся лучей. Радиальные и концентрические линии встречаются как на каменных, так и на глиняных маховичках. Причем приемы эти повторяются на дисках буквально до деталей. К примеру, концентрические окружности, представлены как простыми линиями, так и дополненными декоративными лепестками или завитками. Те же завитки использованы в т.н. «вихревых розетках» (рис. 3: 3). Радиально поставленные лучи наносились и в виде ломаных линий (рис. 3: 10). Концентрический принцип в то же время просматривается не только для окружностей, но и для многоугольных фигур (пятиугольники, ромбы, причем последние вписаны в окружности; рис. 3: 2; 6: 5). Так, на небольшой каменной заготовке диска узоры нанесены столь хаотично, что солярные символы-четырехлучевая звезда, окруженная ячешуйками-ромбами (рис. 5: 1) скорее угадываются. Хотя, при такой схематичности и степени сохранности изображений, не исключено, что это могли быть и тамгообразные знаки (?).

В слоях и объектах пьяноборской эпохи найдено всего 13 дисков (9\% от выборки; рис. 6). Из них 9 дисков глиняных, 2 - каменных и одно - из стенки сосуда. Также преобладают диски типа III (5 экз.), но обращает внимание наличие в этой группе битрапециевидных пряслиц (тип IV), совершенно отсутствовавших в первой группе. В этой группе отсутствуют и орнаментированные диски.
Рис. 8. Зуевоключевское I городище. Стратиграфическое распределение пряслиц

Fig. 8. Zuevoklyuchevskoe I hillfort.

Stratigraphic distribution of spinning wheels

Довольно значительная часть пряслиц происходит из слоев разрушения - 38 (30\%; рис. 7), что не должно удивлять, учитывая степень антропогенного давления на памятник в последнее столетие. Большинство дисков глиняные -31 , каменных -4 , костяных -2 и керамических -1 . В разновременности этой группы пряслиц убеждает как их типологическое разнообразие (например, присутствие в выборке битрапециевидных типа IV), так и особенности орнаментации. Декор отмечен на 9 глиняных дисках. К уже известным узорам, описанным выше в группе ананьинских маховичков (концентрические окружности, округлые вдавления, радиальнолучевые), добавились спираль, выполненная весьма характерными отпечатками шнура, треугольники по внешнему кругу диска, развернутые вершинами к центральному отверстию. Безусловно интересен глиняный диск с тамгообразным знаком (рис. 6: 6).

Таким образом, разнесение дисков по стратиграфическим горизонтам и культурным слоям, не смотря на сильнейшие разрушения верхних слоев и частичное отсутствие информации в материалах раскопок 1970-х годов, позволяет заметить, что на ананьинское время приходится наибольшая часть выборки, на пьяноборское - наименьшая. Вместе с тем, распределение пряслиц достаточно выразительное: ананьинские диски отличались от пьяноборских большим типологическим разнообразием, они в целом массивнее, безусловно, более нарядные. Скорее всего, именно для ананьинского времени характерны каменные диски. Тогда как в пьяноборское время среди глиняных появляются новые типы с битрапециевидным сечением; пряслица теряют декорировку.

Планиграфическое распределение пряслиц. Вновь должна оговориться, что установить связь пряслиц с объектами и слоями, изученными на городище, оказалось возможным только для находок 1997-2005 гг. Таких пряслиц 84. Для 105 дисков возможно установить привязку с точностью до местоположения раскопа в границах площадки городища. 76 пряслиц из 105 (75\%) найдены в северной части площадки, объекты которой связаны с хозяйственнобытовой сферой жизнедеятельности (Черных, 2009, с. 80-81). Еще 4 пряслица найдены в пределах раскопов юго-восточной части горо- 
дища, где также изучены жилища ананьинского времени (Ашихмина, Генинг, 1986). В границах полов жилых сооружений ананьинского времени (IIa, IV, XII, XVII, XXIV, XXVI, XXXIV) найдено 13 дисков. C сооружением IV связаны находки пяти пряслиц; они найдены вблизи очагов и приочажных ям. В жилище XII два глиняных неорнаментированных пряслица были втоптаны в пол. В сооружении XXIV найдено четыре пряслица: три глиняных диска были обнаружены втоптанными в пол жилища, одно - каменное - найдено вблизи очажной ямы. Два диска происходят из жилища XXXIV (найдены на полу, в северовосточном углу сооружения).

Два диска, в том числе одно битрапециевидное, найдены в чегандинском жилище XXVII. Еще два найдены вблизи чегандинского очага XCVIII. Остальные находки локализованы в межжилищном пространстве, но в непосредственной близости от жилищ, хозяйственных ям или очагов.

В центральной части городищенской площадки (раскопы XXIV, XXVII) был изучен крупный производственный объект позднеананьинского времени, о чем позволяют судить необычный для жилых построек интерьер, глубокие ямы с обширными очажными площадками, находки тиглей, шлаков, кусков обмазки горнов). Из сооружения происходят находки пяти дисков (двух глиняных, по одному каменному, керамическому и костяному). Одно из пряслиц украшено округлыми вдавлениями, размещавшимися хаотично по всей поверхности полусферической приканальной площадки (рис. 3: 1). Еще три диска были найдены на участках, примыкающих к сооружению с юга.

В границах святилища, изученного в южной части городищенской площадки, находки пряслиц не обнаруживают скольконибудь характерного распределения (Черных, 2013, рис. 5-3, 4). Четыре диска происходят из слоя разрушения культовой постройки и очага LXIV. Еще три маховичка в этой части городища были найдены в объектах более позднего чегандинского периода (сооружение V и яма 1).

Таким образом, можно считать, что большинство находок пряслиц на городище так или иначе связано с жилищно-хозяйственными объектами, в меньшей степени - с производственной зоной и святилищем.

Специфика зуевоключевских пряслиц будет более очевидна при сравнении их с коллекциями одновременных памятников как
Прикамья, так и сопредельных территорий. Рассмотрим часть из них.

Ананьинские поселения Средней и Верхней Камы изучены достаточно хорошо, чего, к сожалению, нельзя сказать о качестве опубликованности полученных материалов. С Конецгорского поселения-святилища (раскопки А.В. Збруевой) происходят 10 пряслиц: 9 из них каменные, 1 - глиняное (1952, с. 244). Размеры пряслиц вписываются в общие параметры 3,5-5,0 см. При этом, А.В. Збруева отметила, что диски диаметром около 5 см, как правило, более тонкие (толщина 0,5-1,0 см), а диски размером 3,5-4 см имели толщину около 1,5 см. Одно пряслице украшены крестообразно размещенными вокруг центрального отверстия елочками (Збруева, 1952, табл. LXV-7), на втором изображены концентрические окружности с «уголками» по внешнему периметру (Збруева, табл. LXV-6). Удивительно, но с другого значимого памятника ананьинского времени, также раскопанного А.В. Збруевой большой площадью - Галкинского городища - находки пряслиц не упоминаются (Збруева, 1940, с. 83-110). Раскопки городища Ермаши и поселения Тарасово, по лаконичной информации, имеющейся в литературе, дали коллекцию пряслиц, главным образом, прямоугольного сечения (Коренюк, Мокрушин, 2003, с. 16). Авторы небольшой публикации упоминают о пяти декорированных дисках, как из глины, так и каменных. Основные узоры - концентрические окружности (от 1 до 4-х) и радиально расходящиеся линии. Об аналогичных узорах на пряслицах пишет А.Д. Вечтомов, характеризуя материальную культуру среднекамских ананьинцев (1967, c. 147, табл. 1, № 83). В публикации В.А. Борзуновым материалов городища АлтенТау приведены сведения о находках восьми маховичков, семь из которых изготовлены из стенок керамических сосудов, одно - лепное. Последнее близко по форме сечения к полусферическим с вогнутой нижней поверхностью. Диаметр керамических дисков от 3-х до 7,0 см. Орнаментированные пряслица в выборке отсутствовали (Борзунов, 1997, с. 97). Раскопки Усть-Нечкинского городища в 2007-2014, 2017 гг., дали те же характерные признаки позднеананьинского-пьяноборского материального комплекса, что и другие известные городища этого круга. В коллекции из раскопок 1913 г. Л.А. Беркутова ${ }^{2}$ и нашей экспедиции имеются исключительно глиняные пряслица (7 экз.) и керамические диски (6 экз.). Пряслица, в основном, полусфериче- 
ского сечения, единично - прямоугольного. На одном диске вырезана солярная розетка (Черных и др., 2009, рис. 9-3), на двух - одинаковый радиально-лучевой узор, нанесенный ногтевыми отпечатками.

Довольно репрезентативной выборкой пряслиц и качеством их публикации отличается Тарасовское поселение-святилище, датируемым исследователями V-III вв. до н. э. (Голдина и др., 2013, с. 47). Культурный слой этого неординарного объекта сильно разрушен захоронениями Тарасовского могильника $\mathrm{I}-\mathrm{V}$ вв. н.э., что не позволяет детально понять характер его функционирования. Но в контексте интересующего нас вопроса, коллекция маховичков с этого памятника весьма выразительна и прекрасно корреспондируется с аналогичными изделиями Зуевоключевского городища.

Все пряслица Тарасовского святилища изготовлены из глины: 43 вылеплены из сырой глины, 10 - выточены из стенок сосудов. Симптоматично, что на этом, явно позднеананьинском памятнике, отсутствуют каменные диски. Диаметр глиняных пряслиц варьируется от 2,5 до 5,1 см, диаметр отверстия 2,5-7 мм, толщина - от 0,8 до 2,8 см (Голдина и др., 2013, с. 41). Размеры керамических дисков чуть больше - диаметр 2,3-6,0 см, толщина 0,4-0,8 см. Как и в зуевоключевской серии большая часть пряслиц имела прямоугольное (и близкое к нему) сечение, меньше полусферических (в публикации названы коническими) и овально-выпуклых. Два диска по форме заметно выделяются из общей выборки; один имеет битрапециевидное сечение, второй - прямоугольно-трапециевидное (тип VI). Лишь на 9 дисках имелись узоры, правда, характер их исполнения не отличается тщательностью и мастерством: декор нанесен прочерченными или резными линиями, в единственном случае - отпечатками шнура (Голдина, 2013, табл. 19-20). Все отмеченные узоры вписываются в парадигму радиально-концентрических композиций. Одно из тарасовских пряслиц обнаруживает прямое сходство с диском с Зуевоключевского городища (рис. 3: 3). Соответствие прослеживается даже в количестве вихревых завитков (их пять), разница лишь в их направлении - тарасовские закручены «против часовой стрелки», зуевоключевские - «по солнцу». Таким образом, сопоставление двух коллекций, близких территориально и культурно-хронологически, показывает устойчивую тенденцию в предпочтении пряслиц, изготавливавшихся из глиня- ного теста, а также отказу от декорировки дисков при смене ананьинской эпохи пьяноборской. В целом зуевоключевские пряслица обнаруживают очень близкое сходство с камскими ананьинскими в использовании сырья (глина), предпочтении прямоугольной и полусферической формы в сечении дисков, геометрических орнаментов.

А.Х. Халиковым при обобщении материалов раннего этапа ананьинской культуры в 1977 г. были рассмотрены 24 предмета, происходящие из поволжских ананьинских городищ (Васильсурское и Копаньское), поселения Курган и двух могильников (Старший Ахмыловский и Акозинский); среди них по форме сечения выделены 4 типа пряслиц: линзовидные, прямоугольные, битрапециевидные и из стенок сосудов (1977, с. 154). Абсолютно преобладали в выборке линзовидные диски (15 экз.), изготовленные из глины, диаметром 4,0-5,0 см, толщиной 1,0-1,8 см. В равном количестве указаны диски с прямоугольным и битрапециевидным сечением (по 6 экз.). Пряслица с прямоугольным сечением известны из глины, камня и металла. Последние отлиты из бронзы и происходят исключительно из Ст. Ахмыловского могильника (погр. 245 и с участка). Битрапециевидные пряслица имели диаметр 4,0-5,5 см и отличались в среднем большей толщиной (1,3-1,8 cм), но их находки связаны с раннеананьинскими могильниками. Материалы раскопок ананьинских городищ Нижней Камы (Сорочьи Горы, Гремячий Ключ, Елабужское) и могильников (Мурзихинский IV) остаются опубликованными лишь частично. Среди опубликованных выделяются (как по форме, так и орнаменту) глиняное пряслице с Copoчьегорского городища, с высоко приподнятым бортиком вокруг центрального отверстия, украшенное спиралевидным узором, оттиснутым шнуром, дополненным по краю гурта насечками (Руденко, 2002, с. 20, рис. 21-33), а также глиняное биконическое пряслице из Мурзихинского IV могильника, в декоре которого также использован мотив спирали, нанесенной мелкими наколами (Руденко, 2002, с. 25, рис. 27-31). Таким образом, между зуевоключевскими пряслицами и их аналогами на нижнекамских и волжских памятниках заметны некоторые различия, как в выборе формы, так и декора.

На вятском ананьинском Аргыжском городище найдено 40 пряслиц, из них 23 изготовлены из глины и стенок керамических сосудов, 17 - каменные. Диаметр пряслиц в 
среднем близок среднекамским и составляет 4,5 см (наименьший 3 см, наибольший - 6,5 см), толщина в среднем 0,8 см. Глиняные весьма разнообразны по форме - прямоугольные, линзовидные (плоско-выпуклые), блоковидные и т.д., тогда как каменные - почти всегда прямоугольного сечения (Черных, Ванчиков, 2002, с. 47, 49). Почти половина аргыжских пряслиц орнаментирована, причем абсолютное большинство орнаментированных (95\%) изготовлены из камня.

На другом вятском городище, изученном большой площадью - Буйском - коллекция пряслиц представлена почти 80 экземплярами: 10 глиняных, 17 керамических и более чем 50 (25 целых и около 30 в обломках) каменных. Буйские каменные пряслица однотипны (все имеют прямоугольное сечение), тогда как глиняные характеризуются значительной вариативностью - с прямоугольным сечением, округлым, усечено-биконические, усеченоконические, линзовидные. Диаметры каменных пряслиц в среднем составляют около 4,6 см, диаметр центрального отверстия 0,5-0,6 см. Редкие экземпляры с очень маленьким диаметром (около 2,0 см) или, напротив, очень большим диаметром (6,6-8,7 см). Толщина пряслиц - 0,4-1,7 см. Глиняные диски имели диаметр - 3,5-5,0 см при толщине 1,0-1,3 см, но есть и более массивные 2,0-2,3 см. Диаметр керамических варьируется больше - от 2,2 до 5,6 см, при толщине 0,3-0,5 см. Среди каменных дисков орнаментированных - 18 (32,7\%), из них 11 украшены растительно-геометрическими узорами, 7 - зооморфными. Глиняные пряслица украшались значительно скромнее: на 3-х дисках узоры нанесены точечными наколами, на одном - оттисками шнура.

Таким образом, вятские пряслица выразительно отличаются от других регионов ананьинского мира, прежде всего, высокой долей дисков, украшенных сложными, как по композиции, так и исполнению, зооморфными мотивами (Черных, Тищенко, 2006; Митряков, Черных, 2014, с. 166-167).

Пряслица чегандинского времени (городище Чеганда I), изготавливались из глины, или стенок керамических сосудов (В.Ф. Генинг называет последние глиняными кружками $\left.{ }^{3}\right)$. Часть пряслиц из глины, с примесью мелкого песка и хорошим обжигом, как пишет В.Ф. Генинг, имела битрапециевидное сечение, небольшой диаметр - 2,5-3,0 см и толщину 1,0-1,5 см (1971, с. 75, табл. XXVI-1). Другая часть маховичков изготовлена из слабо отформованной глины, с примесью толченой раковины; у этой группы пряслиц форма сечения разнообразная: прямоугольное, полусферическое, блоковидное (Генинг, 1971, табл. XXVI-2-11). Принимая во внимание результаты новых исследований на городище Чеганда I, проведенных Т.И. Останиной в 1998 г., выскажу предположение, что часть опубликованных В.Ф. Генингом пряслиц с городища Чеганда I (в частности, с орнаментом в виде закрученного в спираль шнура, веточек-лучей, а также диска из стенки ананьинского сосуда (1971, табл. XXVI-2, 6, 11), следует считать ананьинскими же. Характеризуя позднее мазунинский комплекс городища В.Ф. Генинг обратил внимание, что пряслица усечено-биконической формы (по сути, битрапециевидные), относятся уже не к чегандинскому, а мазунинскому времени (1967, с. 146). Заметим попутно, что в коллекции Кузебаевского городища V-VII вв. такие пряслица уже абсолютно доминируют (Останина, 2002, с. 22, рис. 7-9).

Традиция украшения пряслиц в пьяноборское время практически изживает себя. Похожий тренд наблюдается и у носителей кара-абызской AK, переживших апогей в декорировании пряслиц в последние три века до рубежа эр (Котов, 2010, с. 41). Для ранних кара-абызских памятников характерны те же типы декорированных пряслиц, что и у ананьинцев. Большинство их изготавливались из камня (тальк или другие мягкие породы), имели цилиндрическое сечение и геометрический (радиально-циркульный) орнамент (Котов, 2010, с. 36).

Для восточных соседей ананьинцев наиболее предметно в научной литературе анализировались диски с иткульских, иткульско-гамаюнских и саргатских памятников (Берсенева, 1999; Чикунова, 2006; Викторова, Непомнящая, 2006; Наумов, Головина, 2017). Для иткульских поселений характерны диски глиняные, керамические (из стенок сосудов) и каменные. Наиболее представительная коллекция маховичков (215 экз.) происходит с Иткульского городища (раскопки К.В. Сальникова и Г.В. Бельтиковой). Абсолютно преобладают среди них диски, изготовленные из стенок сосудов (143 экз.; 66,5\%), лепных только 7, из талькового камня - 65 (30,2\%). 43 диска в коллекции (в основном, каменные) орнаментированы круговыми и радиально-круговыми узорами, реже спиральными (Викторова, Непомнящая, 2006, с. 135). Близкие количественные характеристики имеются для такого памятника как Палатки I, где 
половина пряслиц также были изготовлены из стенок сосудов (22 из 43). Остальные распределялись между лепными (4 экз.), тальковыми (9 экз.) и заготовками изделий. В силу специфики самого памятника подавляющее число дисков были связаны с объектами металлургического характера, а также с культовой площадкой (Викторова, Непомнящий, 2006, c. 130-131). На керамические диски с обоих Иртяшских городищ приходится от 74,8\% (Иртяшское I) до 89,2\% (Иртяшское II). Сами маховички сильно варьируются по форме (как круглые, так и квадратные, и многоугольные) и размерам - от 1,8 до 7,2 см. (Наумов, Головина, 2017, с. 87-89, рис. 1, 3). По наблюдениям публикаторов, для керамических и тальковых пряслиц характерны радиальные и концентрические резные орнаменты, а для глиняных - точки и наколы, располагавшиеся по окружности площадки, насечки - по гурту (Наумов, Головина, 2017, с. 88). Исследователи сходятся на предположении о многовариантном использовании указанных дисков - не только в традиционных прядении и ткачестве, как застежек-пуговиц, но и в металлургии как приспособлений в приводных механизмах, либо в ритуалах добывания огня трением, призванных обеспечить благополучную плавку (Сериков, 1996, с. 63; Бельтикова, 1988 , с. 107; Викторова, Непомнящая, 2006, с. 137-139).

На лесостепных саргатских памятниках, по-видимому, пряслица также изготавливались в абсолютном большинстве случаев из глины; каменные, костяные и металлические изделия единичны (Корякова, 1988, с. 73; Берсенева, 1999; Матвеева, 2008, с. 133-137, рис. 93-95; Чикунова, 2008; Корякова Л.Н. и др., 2009, с. 87-91). Опубликованные материалы как поселений, так и могильников позволяют заключить, что саргатские пряхи предпочитали лепным пряслицам изделия, выточенные из стенок сосудов, имевших к тому же различную культурную идентификацию (саргатские, гороховские, привозные среднеазиатского происхождения). В форме лепных дисков также подчеркивается вариативность их сечений: прямоугольные, конические, биконические, сфероконические, цилиндрические. Размеры довольно стандартны: диаметр 2,5-6 см, толщина 0,5-1,3 см. Но есть и довольно высокие (до 2,9 см). В орнаментации лепных изделий использованы резные концентрические, радиально-лучевые узоры, насечки, ямочные вдавления; выточенные из стенок сосудов - орнаментация и техно- логические особенности соответствующей керамики. Отмечается также связь находок пряслиц на поселениях с жилыми объектами; их возможная (особенно тех, что выточены из стенок сосудов) многофункциональность (Чикунова, 2008, с. 126). Н.А. Берсенева, проанализировавшая встречаемость керамических пряслиц в погребениях саргатской АК, пришла к выводу, что они в равной степени встречаются как в женских, так и в «мужских наборах». В последних пряслица присущи, в том числе, мужчинам весьма высокого социального статуса (Берсенева, 1999, с. 117). В.Д. Викторова рассматривает это обстоятельство как дополнительный аргумент в пользу использования пряслиц в мужской субкультуре раннего железного века в связи с металлургией и военным делом (2006, с. 142).

Западнее ананьинского ареала известны многочисленные городища дьяковской археологической культуры. В классификации дьяковских пряслиц, предложенной К.А. Смирновым, учтены только диски из стенок сосудов и глины: биконические в сечении, овальные и прямоугольные, достаточно стандартных размеров (диаметр 2,0-3,0 см, диаметр центрального отверстия 0,6-1,0 см, толщина 1,0-1,5см), причем биконические статистически самый массовый тип (Смирнов, 1974, с. 67). А.Ф. Дубынин публикуя материалы раскопок Троицкого и Щербинского городищ, останавливается на характеристике пряслиц более детально (1970, с. 42-43; 1974 , c. 240). Коллекции дисков с обоих городищ при сравнении весьма различны. Так, пряслица Щербинского городища изготовлены, в основном, из глины (но имеются и каменные, правда, количество их в публикации не указано); имеют весьма вариативные размеры и сечение, причем преобладают овальные, уплощенно-овальные, усечено-конические и битрапециевидные; глиняные украшены беспорядочными ямочными вдавлениями и гребенчатым штампом (Дубынин, 1974, табл. XXI-16, 18). Пряслица Троицкого городища морфологически более единообразны: и глиняные и каменные диски имели только овальную и усечено-коническую в сечении форму. Орнаментированных изделий среди них нет. А.Ф. Дубыниным замечена связь биконических дисков только с верхними напластованиями слоя. Заметим также, что на Щербинском городище имеются костяные экземпляры пряслиц (Дубынин, 1974, с. 223). Известны аналогичные предметы и в коллекции эпонимного памятника - Дьякова 
городища, правда, Н.А. Кренке предпочитает их пряслицами не называть, определяя, что, впрочем, вполне резонно, как просверленные суставные головки (2011, рис. 105). Столь же осторожно он не называет пряслицами все глиняные и каменные диски с отверстиями, а только изделия с битрапециевидным и биконическим сечением (Кренке, 2011, с. 63). Важно, что четко документировано их появление в среднем горизонте верхнего слоя, дата для которого предложена по выразительной серии привозных изделий, в том числе бус, конец II - сер. IV вв. н. э. (Кренке, Румянцева, 2011, c. 85).

Bblводыl. Подводя итоги рассмотрению пряслиц Зуевоключевского I городища в Нижнем Прикамье, можно высказать следующие важные замечания. Специфические черты этой категории вещественных источников для отдельного памятника выявляются при рассмотрении морфологии, размеров, декора пряслиц, в культурно-хронологическом и топографическом аспектах. Прежде всего, материалом для изготовления пряслиц чаще всего служила глина. От одновременных зауральских и западно-сибирских маховичков ананьинские явно отличает соотношение изделий из глины и битых керамических сосудов в пользу первых. К западу от Волги, на дьяковских городищах, также преобладали пряслица, формованные из глины, но до рубежа новой эры, по всей видимости, предпочтение отдавалось овальной форме сечения дисков, тогда как на камских - прямоугольной. К рубежу эр овальная форма начинает вытесняться битрапециевидной, у таких коле- сиков увеличивается диаметр центрального отверстия. В Поволжье и Прикамье подобные пряслица появляются, по-видимому, несколько позднее, возможно, вместе «с западным импульсом».

Внутри ананьинского ареала можно также говорить о некоторых локальных и, вероятно, хронологических отличиях в изготовлении пряслиц. При той неполноте публикаций, что мы имеем на сегодняшний день, безусловно, выводы будут выглядеть преждевременными. Но все же отважусь высказать мнение, что со среднекамскими ананьинскими коллекциями пряслиц зуевоключевские сближает использование глины, прямоугольное сечение дисков, орнаментальные приемы и элементы. Вятские, о чем уже приходилось писать, отличает обилие каменных декоративных (зооморфизм) изделий. Поволжские пряслица, судя по статистике, приведенной А.Х. Халиковым, также изготавливались, в основном, из глины, но в форме сечения предпочтение отдавалось линзовидным (овальным) дискам. В чегандинское время традиция украшения пряслиц сходит на нет.

$\mathrm{He}$ все приводимые диски, очевидно, можно ассоциировать с прядением. Метрические характеристики, как и некоторые своеобразные формы дисков, позволяют искать иные варианты использования. На Зуевоключевском I городище топография находок все же склоняет более к хозяйственно-бытовой функции анализируемых предметов, но не исключает и их применение в иных сферах жизнедеятельности (культовой, производственной).

\section{Примечания:}

${ }^{1}$ В полевых материалах В.Ф. Генинга и Л.И. Ашихминой не удалось обнаружить картографических планов, а в полевых описях отсутствует указание на характер слоя, в котором найдены предметы.

${ }^{2}$ Сохранившаяся в очень неполном виде коллекция этих раскопок была опубликована в небольшом сборнике Сарапульского историко-архитектурного музея-заповедника (Черных, Перевозчикова, Митряков, 2009), Выражаю также признательность С.А. Перевозчиковой, познакомившей меня с неопубликованными материалами ее раскопок Усть-Нечкинских городищ.

${ }^{3}$ Описанные исследователем городища диски не имели правильной формы и обладали очень узким отверстием, неперпендикулярным плоскости кружка (Генинг, 1971, с. 74)

\section{ЛИТЕРАТУРА}

Ашихмина Л.И. Реконструкция представлений о Мировом древе у населения Северного Приуралья в эпоху бронзы и раннего железа / Сер. препринтов «Научные доклады». Вып. 298. Сыктывкар, 1992. $30 \mathrm{c}$.

Ашихмина Л.И. Генезис ананьинской культуры в Среднем Прикамье (по материалам керамики и жилищ) / Археология Евразийских степей. Вып. 19. Казань: ИА АН РТ; Отечество, 2014. 300 с.

Ашихмина Л.И., Генинг В.Ф. Ананьинские жилища Зуево-Ключевского I городища // Памятники материальной культуры на Европейском Северо-Востоке / Материалы по археологии Европейского Северо-Востока. Вып. 10. / Отв. ред. В.И. Канивец. Сыктывкар: Коми кн.изд., 1986. С. 54-70. 
Бельтикова Г.В. Памятник металлургии на острове Малый Вишневый // Материальная и духовная культура древнего населения Урала и Западной Сибири / ВАУ. Вып. 19 / Отв. ред. В. Т. Ковалева. Свердловск: УрГУ, 1988. С. 103-117.

Беркутов Л.А. Разведки и раскопки, произведенные Л.А. Беркутовым по поручению Сарапульского земского музея в 1910-13 гг. // Известия Сарапульского земского музея. Вып. 2. М.: Печатня С.П. Яковлева, 1914. С. 35-89.

Берсенева Н.А. Керамические пряслица из погребений саргатской культуры (по материалам Среднего Прииртышья) // XIV Уральское археологическое совещание (21-24 апреля 1999 г.).: Тезисы докладов / Отв. ред. С.А. Григорьев. Челябинск: Рифей, 1999. С. 115-117.

Борзунов B.A. Новые материалы по раннему железному веку Прикамья (городище Алтен-Тау) // РА. 1997. № 2. C. 197-210.

Вечтомов А.Д. Периодизация и локальные группы памятников ананьинской культуры Среднего Прикамья // Ученые записки ПГУ. № 148. Пермь, 1967. С. 133-155.

Черных Е.M., Тищенко И.Г. «Свернувшийся зверь»-волк, медведь, дракон? (К вопросу о появлении мотива в декоре пряслиц ананьинской культуры) // Пятые Берсовские чтения /Отв. ред В.М. Морозов. Екатеринбург: Квадрат, 2006. С. 125-129.

Вязников А.М., Дерендяев Д.С., Черных Е.M. Исследования памятников раннего железного века Зуево-Ключевского микрорайона // АО 1999 года / Отв. ред. В.В. Седов, Н.В. Лопатин. М.: Наука, 2001. C. $179-181$.

Генинг В.Ф. История населения Удмуртского Прикамья в пьяноборскую эпоху. Чегандинская культура (ІІІ в. до н.э. - ІІ в. н.э.) Ч. І. // ВАУ. Вып. 10 / Отв. ред. В.А. Семенов. Ижевск, 1970. 257 с.

Генинг В.Ф. История населения удмуртского Прикамья в пьяноборскую эпоху. Ч. II / Археологические памятники чегандинской культуры (III в. до н.э. - ІІ в. н.э.) / ВАУ. Вып. 11 / Отв. ред. В.А. Семенов. Свердловск-Ижевск, 1971. 159 с.

Генинг В.Ф. Городище Чеганда I в мазунинское время // Памятники мазунинской культуры / ВАУ. Вып. 7. / Отв. ред. А.Ф. Медведев. Свердловск, 1967. С. 141-161.

Генинг В.Ф., Ашихмина Л.И. Зуево-Ключевская стоянка // Археолого-этнографические аспекты изучения Северного Приуралья / отв. ред. Л.Н. Жеребцов. Сыктывкар: Коми филиал АН СССР, 1984. C. $123-137$.

Голдина Р.Д. Зуевы Ключи - археологический заповедник Удмуртского Прикамья // Удмуртская республика: проблемы и перспективы / Под ред. 3. А. Богомоловой. Ижевск, 1995. С. 34-48.

Голдина Р.Д., Колобова Т.А., Казаниеева О.А., Митряков А.Е., Шаталов В.А. Тарасовское святилище раннего железного века в среднем Прикамье / МИКВАЭ. Т. 26. Ижевск, 2013. 184 с.

Голдина Р.Д., Черных Е.M. Археологическая карта Каракулинского района Удмуртской Республики. Ижевск: УдГУ, 2011. 162 с.

Дубынин А.Ф. Троицкое городище // МИА. № 156. М. Наука, 1970. С. 5-98.

Дубынин А.Ф. Щербинское городище // Дьяковская культура / Отв. ред. Ю.А. Краснов. М.: Наука, 1974. С. $198-281$.

Журбин И.В. Геофизика в археологии: методы, технология и результаты применения. Ижевск: УИИЯЛ УрО РАН, 2004. 152 с.

Збруева А.В. Галкинское городище // МИА. № 1 / Под ред. П.Н. Третьякова. М.-Л.: Изд-во АН СССР, 1940. C. 83-100.

Збруева A.B. История населения Прикамья в ананьинскую эпоху / Материалы и исследования по археологии Урала и Приуралья. Т. V / МИА. № 30. М.: Изд-во АН СССР, 1952. 326 с.

Карпушкина О.А. Место Зуевоключевского III (Хижняковского) городища в системе Зуевоключевского археологического микрорайона железного века // VII научно-практическая конференция преподавателей и сотрудников УдГУ, посвященная 245-летию Ижевска. Ч. 1. / Под ред. В.А. Журавлева. Ижевск: УдГУ, 2005. С. 109-110.

Карпушкина O.A., Черных E.M. Новые данные о расселении в Удмуртском Прикамье на рубеже новой эры // Пермские финны: археологические культуры и этносы. Материалы I Всероссийской научной конференции (25-28 сентября 2007 г.) / Ред. Э.А. Савельева. Сыктывкар, 2007. С. 88-91.

Коренюк С.Н., Мокрушин В.П. Археологические памятники на Земле Пермской. Пермь: Арабекс, 2003. $20 \mathrm{c}$.

Корепанов К.И., Обыденнов М.Ф. Художественные стили в искусстве ананьинской эпохи // У истоков археологии Волго-Камья (к 150-летию открытия Ананьинского могильника) / Ред. С.В. Кузьминых, А.А. Чижевский / Археология евразийских степей. Вып. 8. Елабуга: ИИ АН РТ, 2009. С. 213-215.

Корякова Л.Н. Ранний железный век Зауралья и Западной Сибири (саргатская культура). Свердловск: Изд-во Уральского ун-та, 1988. 241 с.

Корякова Л.Н., Дэйр М.И., Ковригин А.А., Шарапова С.В., Берсенева Н.А., Пантелеева С.Е., Ражев Д.И., Курто П., Хэнкс Б., Ефимова Е.Г., Микрюкова О.В., Сахарова А.О. Среда, культура и общество 
лесостепного Зауралья во второй половине I тыс. до н. э. (по материалам Павлиновского археологического комплекса). Екатеринбург-Сургут: Магеллан, 2009. 298 с.

Косарев М.Ф. Основы языческого миропонимания: по сибирским археолого-этнографическим данным. М.: Ладога-100, 2003. 352 с.

Котов В.Г. Семантика пряслиц кара-абызской культуры раннего железного века Приуралья // УАВ. 2010. №. 10. C. 36-55.

Кренке Н.А. Дьяково городище: культура населения бассейна Москвы-реки в I тыс. до н. э. - I тыс. н. э. М.,: ИА РАН, 2011. 548 с.

Кренке Н.А., Румянцева О.С. Стеклянные бусы из верхнего слоя Дьякова городища // Кренке Н.А. Дьяково городище: культура населения бассейна Москвы-реки в I тыс. до н.э. - I тыс. н.э. М.: ИА РАН, 2011. С. $82-88$.

Марков В.Н. Ананьинская проблема (некоторые итоги и задачи ее решения) // Памятники древней истории Волго-Камья / Отв. ред. П.Н. Старостин. Казань: ИЯЛИ им. Г. Ибрагимова, 1994. С. $48-88$.

Матвеева Н.П., Берлина С.В., Рафикова Т.Н. Коловское городище. Новосибирск: Наука, 2008. 240 с.

Митряков A.E., Черных E.M. Вятские древности начала железного века: полтора столетия после открытия культуры «костеносных городищ» // Ананьинский мир: истоки, развитие, связи, исторические судьбы / Археология Евразийских степей. Вып. 20 / Отв. ред.: С.В. Кузьминых, А.А. Чижевский. Казань: Отечество, 2014. С. 147-186.

Митряков A.E., Черных E.M. Абсолютная и относительная хронология Зуевоключевского I городища: проблемы сопоставления // Археология Евразийских степей. 2017. №4. С. 17-32.

Наумов А.М., Головина Е.Ю. Пряслица иртяшских городищ // Этнические взаимодействия на Южном Урале. Сарматы и их окружение: материалы VII Всерос. (с междунар. участием) науч. конф. / отв. ред. А.Д. Таиров. Челябинск, 2017. С. 86-91.

Останина Т.И. Кузебаевское городище IV-V, VII вв. Каталог археологической коллекции. Ижевск: ИД «Удмуртский университет», 2002. 112 с.

Перевощиков С.Е. Исследования памятников в д. Зуевы Ключи // АО 1998 года / Отв. ред. В.В. Седов, Н.В. Лопатин.. М.: Наука, 2000. С. 250-251.

Руденко К.A. Остров «Мурзиха» и его окрестности. Хронологический атлас археологических коллекций НМ РТ (1991-1999 гг.): Опыт микрорегионального исследования: Каталог археологических коллекций НМ РТ. Казань: Школа, 2002. 208 с.

Сериков Ю.Б. К вопросу о сакральном и функциональном назначении так называемых пряслиц // ХІІІ Уральское археологическое совещание. Тезисы. Ч. 1 / Отв. ред. В.А. Иванов. Уфа: Изд-во Восточный университет, 1996. С. 34-36.

Смирнов К.А. Дьяковская культура (материальная культура городищ междуречья Оки и Волги // Дьяковская культура / Отв. ред. Ю. А. Краснов. М.: Наука, 1974. С. 102-139.

Спищылн A.A. Приуральский край. Археологические розыскания о древнейших обитателях Вятской губернии // МАВГР. Вып. І. М.: Типография Э. Лисснера и Ю. Романа, 1893. 192 с.

Фоломеев Б.А., Чернай И.П. К вопросу о раннем ткачестве в лесной полосе Восточной Европы // История и культура Евразии по археологическим данным / Труды ГИМ. Вып. 51. /. Под ред. Т.Б. Поповой и др. М.: Наука, 1980. С. 49-52.

Халиков А.Х. Волго-Камье в начале эпохи раннего железа (VIII-VI вв. до н. э.). М.: Наука, 1977. 264 c.

Черных E.M. Зуевоключевское I городище в Удмуртском Прикамье: некоторые итоги исследований // Удмуртской археологической экспедиции - 50 лет / Ред. М.Г. Иванова. Ижевск: УИИЯЛ УрО РАН, 2004. C. 113-131.

Черных E.M. Некоторые итоги изучения культурного слоя Зуевоключевского I городища в Удмуртском Прикамье. // У истоков археологии Волго-Камья (к 150-летию открытия Ананьинского могильника) / Ред. С.В. Кузьминых, А.А. Чижевский / Археология евразийских степей. Вып. 8. Елабуга: ИИ АН РT, 2009. С. 76-97.

Черных E.M. О хронологии культурного слоя Зуевоключевского I городища в Удмуртском Прикамье // Древности Прикамья эпохи железа: хронологическая атрибуция / МИКВАЭ. Т. 25. / Ред. Л.И. Липина, Н.Ф. Широбокова. Ижевск: Удмуртский университет, 2012. С. 113-123.

Черных E.M. Позднеананьинское святилище на Зуевоключевском I городище (Нижнее Прикамье) // Поволжская археология. 2013. №1(1). С. 153-165.

Черных E.M. На перекрестке речных путей: об особенностях функционирования ананьинского городища у д. Зуевы Ключи в Нижнем Прикамье // Stratum plus. 2018. № 3. С. 267-290.

Черных E.M., Ванчиков В.В., Шаталов В.А. Аргыжское городище на реке Вятке. М.: Ин-т компьютер. исследований, 2002. 188 с.

Черных E.M., Колобова Т.А. Глиняные фигурки Зуевоключевского I городища и некоторые вопросы их назначения и семантики // РА. 2006. №4. С. 145-151. 
Черных Е.M., Перевозчикова С.А., Митряков А.Е. Археологические коллекции Сарапульского музея из раскопок Л.А. Беркутова // «100 лет - это повод». Материалы научно-практической конференции «Институт культуры: баланс традиций и новаций» / сост. Лукас О.Г. Сарапул: Сарапульская типография, 2009. С. 40-48.

Черных Е.M., Тищенко И.Г. «Свернувшийся зверь»- волк, медведь, дракон? (К вопросу о появлении мотива в декоре пряслиц ананьинской культуры) // Пятые Берсовские чтения /Отв. ред В.М. Морозов. Екатеринбург: Квадрат, 2006. С. 125-129.

Черных E.M., Цыгвинцева T.A. Каменные диски с Зуевоключевского I городища // Южный Урал и сопредельные территории в скифо-сарматское время / Отв. ред. Г.Т. Обыденнова, Н.С. Савельев. Уфа: Гилем, 2006. С.180-186.

Чикунова И.Ю. Пряслица Рафайловского селища // Вестник археологии, антропологии и этнографии. 2002. Вып 4. С. 119-126.

\section{Информация об авторе:}

Черных Елизавета Михайловна, кандидат исторических наук, доцент, профессор кафедры истории Удмуртии, археологии и этнологии Удмуртского государственного университета (г. Ижевск, Россия); emch59@mail.ru

\section{REFERENCES}

Ashikhmina, L. I. 1992. Rekonstruktsiia predstavlenii o Mirovom dreve u naseleniia Severnogo Priural'ia $v$ epokhu bronzy i rannego zheleza (Reconstruction of the Concepts of the World Tree across the Population of the Northern Urals in the Bronze Age and Early Iron Age). Syktyvkar (in Russian).

Ashikhmina, L. I. 2014. Genezis anan'inskoi kul'tury v Srednem Prikam'e (po materialam keramiki $i$ zhilishch) (Genesis of the Ananyino Culture in the Middle Kama Area (According to the Ceramics and Dwellings)). Series: Arkheologiia evraziiskikh stepei (Archaeology of the Eurasian Steppes) 19. Kazan: Institute of Archaeology named after A. Kh. Khalikov, Tatarstan Academy of Sciences; "Otechestvo" Publ. (in Russian).

Ashikhmina, L. I., Gening, V. F. 1986. In Kanivets, V. I. (ed.). Pamiatniki material'noi kul'tury na Evropeiskom Severo-Vostoke (Monuments of Material Culture in the European North-East). Series: Materialy po arkheologii Evropeiskogo Severo-Vostoka (Materials on the Archaeology of the European North-East). 10. Syktyvkar: "Komi book publishing House" Publ., 54-70 (in Russian).

Bel'tikova, G. V. 1988. In Kovaleva, V. T. (ed.). Material'naia i dukhovnaia kul'tura drevnego naseleniia Urala i Zapadnoi Sibiri (Material and Spiritual Culture of the Ancient Population of the Urals and Western Siberia). Series: Voprosy arkheologii Urala (Issues the Urals Archaeology) 19. Sverdlovsk: Ural State University, 103-117 (in Russian).

Berkutov, L. A. 1914. In Izvestiia Sarapul'skogo zemskogo muzeia (Proceedings of Sarapul Local Museum). Moscow: "Pechatnya S.P. Yakovleva" Publ., 35-89 (in Russian).

Berseneva, N. A. 1999. In Grigor'ev, S. A. (ed.). XIV Ural'skoe arkheologicheskoe soveshchanie $\left(14^{\text {th }}\right.$ Ural Archaeological Conference). Cheliabinsk: "Rifei” Publ., 115-117 (in Russian).

Borzunov, V. A. 1997. In Rossiiskaia Arkheologiia (Russian Archaeology) (2), 197-210 (in Russian).

Vechtomov, A. D. 1967. In Uchenye zapiski Permskogo gosudarstvennogo universiteta. (Scientific Bulletin of the Perm State University) 148. Perm: Perm State University, 133-155 (in Russian).

Chernykh, E. M., Tishchenko, I. G. 2006. In Morozov, V. M. (ed.). Piatye Bersovskie chteniia (Fifth Bers Readings). Yekaterinburg: "Kvadrat" Publ., 154-177 (in Russian).

Vyaznikov, A. M., Derendyaev, D. S., Chernykh, E. M. 2001. In Sedov, V. V., Lopatin, N. V. (eds.). Arkheologicheskie otkrytiia 1999 goda (Archaeological Discoveries of 1999). Moscow: "Nauka" Publ., 179-181 (in Russian).

Gening, V. F. 1970. Istoriia naseleniia Udmurtskogo Prikam'ia v p’ianoborskuiu epokhu. Ch. I. Chegandinskaia kul 'tura (III v. do n.e. - II v. n.e.) (History of Udmurt Kama Population in the Pyany Bor epoch. Part I. The Cheganda culture ( $3^{\text {rd }}$ Century $B C-2^{\text {nd }}$ Century $\left.A D\right)$ ). In Semenov, V. A. (ed.). Voprosy arkheologii Urala (Issues of the Ural Archaeology) 10. Izhevsk (in Russian).

Gening, V. F. 1971. Istoriia naseleniia Udmurtskogo Prikam'ia v p'ianoborskuiu epokhu. Ch. II. Arkheologicheskie pamiatniki chegandinskoi kul'tury (III v. do n.e. - II v. n.e.) (History of Udmurt Kama Population in the Pyany Bor epoch. Part II. Cheganda Culture Archaeological Sites ( $3^{\text {rd }}$ Century BC $-2^{\text {nd }}$ Century AD)) In Semenov, V. A. (ed.). Voprosy arkheologii Urala (Issues of the Ural Archaeology) 11. Sverdlovsk; Izhevsk (in Russian).

Gening, V. F. 1967. In Medvedev, A. F. (ed.). Pamiatniki mazuninskoi kul'tury (Sites of the Mazunino Culture). Series: Voprosy arkheologii Urala (Issues of the Ural Archaeology) 7. Sverdlovsk, $141-161$ (in Russian).

Gening, V. F., Ashikhmina, L. I. 1984. In Zherebtsov, L. N. (ed.). Akheologo-etnograficheskie aspekty izucheniia Severnogo Priural'ia (Archaeological and Ethnographic Aspects of the Study of the Northern Urals). Syktyvkar: "Komi book publishing House” Publ., 123-137 (in Russian). 
Goldina, R. D. 1995. In Bogomolova, Z. A. (ed.). Udmurtskaia Respublika: problemy i perspektivy (The Udmurt Republic: Issues and Prospects). Izhevsk, 34-48 (in Russian).

Goldina, R. D., Kolobova, T. A., Kazantseva, O. A., Mitriakov, A. E., Shatalov, V. A. 2013. Tarasovskoe sviatilishche rannego zheleznogo veka v srednem Prikam'e (Early Iron Age Sanctuary Tarasovo in the Middle Kama River Basin). Series: Materialy i issledovaniia Kamsko-Viatskoi arkheologicheskoi ekspeditsii (Proceedings and Research of the Kama-Vyatka Archaeological Expedition) 26. Izhevsk (in Russian).

Goldina, R. D., Chernykh, E. M. 2011. Arkheologicheskaia karta Karakulinskogo raiona Udmurtskoi Respubliki (Archaeological Map of the Karakulinsky District of the Udmurt Republic). Izhevsk: Udmurt State University (in Russian).

Dubynin, A. F. 1970. In Materialy i issledovaniia po arkheologii (Materials and Research in Archaeology) 156. Moscow: "Nauka" Publ., 5-98 (in Russian).

Dubynin, A. F. 1974. Krasnov, Yu. A. (ed.). D'iakonovskaia kul 'tura (Dyakovo Culture). Moscow: "Nauka" Publ., 198-281 (in Russian).

Zhurbin, I. V. 2004. Geofizika v arkheologii: metody, tekhnologiia i rezul'taty primeneniia (Geophysics in Archaeology: Methods, Technology and Application Results). Izhevsk: Udmurt Institute of History, Language, and Literature, Ural Branch of the Russian Academy of Sciences (in Russian).

Zbrueva, A. V. 1940. In Tretyakov P. N. (ed.). Materialy $i$ issledovaniia po arkheologii (Materials and Studies in the Archaeology) 1. Moscow-Leningrad: Academy of Sciences of the USSR, 83-100 (in Russian).

Zbrueva, A. V. 1952. Istoriia naseleniia Prikam 'ia v anan'inskuiu epokhu (History of the Population of the Kama River Region in the Ananyino Time). Series: Materialy i issledovaniia po arkheologii Urala i Priural'ia (Materials and Research on the Archaeology of Ural and the Cis-Urals Area) V. Materialy i issledovaniia po arkheologii SSSR (Materials and Research in the USSR Archaeology) 30. Moscow: Academy of Sciences of the USSR (in Russian).

Karpushkina, O.A. 2005. In Zhuravlev, V.A. (ed.).VII nauchno-prakticheskaia konferentsiia prepodavatelei i sotrudnikov Udmutskogo gosudarstvennogo universiteta, posviashchennaia 245-letiiu Izhevska (The 7th Scientific and Practical Conference of Teachers and Specialists of the Udmurt State University Dedicated to the 245th Anniversary of Izhevsk). 1. Izhevsk: Udmurt State University, 109-110 (in Russian).

Karpushkina, O. A., Chernykh, E. M. 2007. In Savelyeva, E. A. (ed.). Permskie finny: arkheologicheskie kul tury i etnosy (Permian Finns: archaeological cultures and ethnic groups). Syktyvkar, 88-91 (in Russian).

Korenyuk, S. N., Mokrushin, V. P. 2003. Arkheologicheskie pamiatniki na Zemle Permskoi (Archaeological Sites on Perm Land). Perm: "Arabeks" Publ. (in Russian).

Korepanov, K. I., Obydennov, M. F. 2009. In Kuzminykh, S. V., Chizhevsky, A. A. (eds.). U istokov arkheologii Volgo-Kam'ia (k 150-letiiu otkrytiia Anan'inskogo mogil'nika) (At the Origins of Archaeology of the Volga-Kama Region (on the 150 th Anniversary of Discovery of the Ananyino Burial Ground)). Series: Archaeology of the Eurasian Steppes 8. Yelabuga: Institute of History named after Sh. Mardzhani, Tatarstan Academy of Sciences, 213-215 (in Russian).

Koriakova, L. N. 1988. Ranniy zhelezniy vek Zaural'ya i Zapadnoy Sibiri (sargatskaya kul'tura (The Early Iron Age in the Trans-Urals and Western Siberia (Sargatka Culture)). Sverdlovsk: Ural State University (in Russian).

Koryakova, L. N., Deier, M. I., Kovrigin, A. A., Sharapova, S. V., Berseneva, N. A., Panteleeva, S. E., Razhev, D. I., Kurto, P., Hanks, B., Efimova, E. G., Mikriukova, O. V., Sakharova, A. O. 2009. Sreda, kul'tura i obshhestvo lesostepnogo Zaural'ia vo vtoroi polovine I tys. do n. e. (po materialam Pavlinovskogo arkheologicheskogo kompleksa (The Environment, Culture and Society of the Forest-Steppe Trans-Urals in the Second Half of $1^{\text {st }}$ Millennium BC (Based on the Materials of Pavlinovo Archaeological Complex). Ekaterinburg, Surgut: "Magellan" Publ. (in Russian).

Kosarev, M. F. 2003. Osnovy iazycheskogo miroponimaniia: po sibirskim arkheologicheskim dannym (Foundations of the Pagan Worldview: Based on Siberian Archaeological and Ethnographic Data). Moscow: "Ladoga-100" Publ. (in Russian).

Kotov, V. G. 2010. Ufimskii arkheologicheskii vestnik (Ufa Archaeological Herald) (10), 36-55 (in Russian).

Krenke, N. A. 2011. Diakovo gorodishche: kultura naseleniya basseyna Moskvy-reki v I tys. do n. e. - I tys. $n$. e. (Dyakovo Hillfort: culture of the population of the Moscow River basin in the $1^{\text {st }}$ Millennium BC $-1^{\text {st }}$ Millennium BC). Moscow: Institute of Archaeology, Russian Academy of Sciences (in Russian).

Krenke, N. A., Rumyantseva, O. S. 2011. In Krenke, N. A. Diakovo gorodishche: kultura naseleniya basseyna Moskvy-reki v I tys. do n. e. - I tys. n. e. (Dyakovo Hillfort: culture of the population of the Moscow River basin in the $1^{\text {st }}$ Millennium $B C-1^{\text {st }}$ Millennium BC). Moscow: Institute of Archaeology, Russian Academy of Sciences, 82-88 (in Russian).

Markov, V. N. 1994. In Starostin, P. N. (ed.) Pamiatniki drevnei istorii Volgo-Kam'ia (Monuments of the Ancient History of the Volga-Kama Region). Kazan: Institute for Language, Literature and History named after G. Ibragimov, 48-88 (in Russian). 
Matveeva, N. P., Berlina, S. V., Rafikova, T. N. 2008. Kolovskoe gorodishche (Kolovskoye fortified settlement). Novosibirsk: "Nauka" Publ. (in Russian).

Mitryakov, A. E., Chernykh, E. M. 2014. In Kuzminykh, S. V., Chizhevsky, A. A. (eds.). Anan'inskii mir: istoki, razvitie, sviazi, istoricheskie sud'by (The World of Ananyino: Origins, Evolution, Relations, Historical Fate). Series: Arkheologiia Evraziiskikh stepei (Archaeology of Eurasian Steppes) 20. Kazan: "Otechestvo" Publ., 147-186 (in Russian).

Mitryakov, A. E., Chernykh, E. M. 2017. In Arkheologiia Evraziiskikh stepei (Archaeology of Eurasian Steppes) 4, 17-32 (in Russian).

Naumova, A. M., Golovina, E. Yu. 2017. In Tairov, A. D. (ed.). Etnicheskie vzaimodeistviia na Iuzhnom Urale. Sarmaty $i$ ikh okruzhenie (Ethnic Interactions in the Southern Urals. The Sarmatians and Their Neighborhood). Chelyabinsk, 86-91 (in Russian).

Ostanina, T. I. 2002. Kuzebaevskoe gorodishche IV-V, VII v. (Kuzebaevskoe Settlement of the 4th-5th and 7th Centuries). Izhevsk: Udmurt State University (in Russian).

Perevoshchikov, S. E. 2000. In Sedov, V. V., Lopatin, N. V. (eds.). Arkheologicheskie otkrytiia 1998 goda (Archaeological Discoveries of 1998). Moscow: "Nauka" Publ., 250-251 (in Russian).

Rudenko, K. A. 2002. Ostrov «Murzikha» i ego okrestnosti. Khronologicheskii atlas arkheologicheskikh kollektsii NM Respubliki Tatarstan (1991 - 1999 gg.) Opyt mikroregional 'nogo issledovaniia. Katalog arkheologicheskikh kollektsii NM Respubliki Tatarstan (Murzikha Island and Its Environs. Chronological Atlas of Archaeological Collections of Tatarstan National Museum (1991 - 1999). An Experience of Microregional Research. Catalog of Archaeological Collections of Tatarstan National Museum). Kazan: "Shkola" Publ. (in Russian).

Serikov, Yu. B. 1996. In Ivanov, V. A. (ed.) XIII Ural'skoe arkheologicheskoe soveshchanie. Tezisy. Ch. 1 (13 th Ural Archaeological Readings. Proceedings. Part 1). Ufa: "Vostochnyi universitet" Publ., 34-36 (in Russian).

Smirnov, K. A.1974. Krasnov, Yu. A. (ed.). D'iakonovskaia kul 'tura (Dyakovo Culture). Moscow: "Nauka" Publ., 102-139 (in Russian).

Spitsyn, A. A. 1893. In Priural'skii krai. Arkheologicheskie rozyskaniia o drevneishikh obitateliakh Viatskoi gubernii (Priuralsky Region. Archaeological Investigations of the Ancient Inhabitants of Vyatka Governorate). Materialy po arkheologii vostochnykh gubernii Rossii (Materials on the Archaeology of Eastern Russian Governorates) 1. Moscow: "Tipografiia E. Lissnera i Yu. Romana" Publ. (in Russian).

Folomeev, B. A., Chernay, I. P. 1980. In Popova, T. B. et al. (eds.). Istoriia i kul'tura Evrazii po arkheologicheskim dannym (History and culture of Eurasia Based on Archaeological Data). Series: Trudy Gosudarstvennogo istoricheskogo muzeia (Proceedings of the State Historical Museum) 51. Moscow: "Nauka" Publ., 49-52 (in Russian).

Khalikov, A. Kh. 1977. Volgo-Kam'e v nachale epokhi rannego zheleza. VIII-VI vv. do n. e. (The VolgaKama Region in the Beginning of the Early Iron Age ( $8^{\text {th }}-6^{\text {th }}$ Centuries $\left.B C\right)$ ). Moscow: "Nauka" Publ. (in Russian).

Chernykh, E. M. 2004. In Ivanova, M. G. (ed.). Udmurtskoi arkheologicheskoi ekspeditsii - 50 let (50th Anniversary of Udmurt Archaeological Expedition) Izhevsk: Udmurt Institute of History, Language and Literature, Ural Branch of the Russian Academy of Sciences, 113-131 (in Russian).

Chernykh, E. M. 2009. In Kuzminykh, S. V., Chizhevsky, A. A. (eds.). U istokov arkheologii Volgo-Kam 'ia (k 150-letiiu otkrytiia Anan'inskogo mogil'nika) (At the Origins of Archaeology of the Volga-Kama Region (on the 150 th Anniversary of Discovery of the Ananyino Burial Ground)). Series: Archaeology of the Eurasian Steppes 8. Yelabuga: Institute of History named after Sh. Mardzhani, Tatarstan Academy of Sciences, 76-97 (in Russian).

Chernykh, E. M. 2012. In Lipina, L. I., Shirobokova, N. F. (eds.). Drevnosti Prikam'ia epokhi zheleza: khronologicheskaia atributsiia (Iron Age Antiquities of the Kama Area: Chronological Attribution). Series: Materialy i issledovaniia Kamsko-Viatskoi arkheologicheskoi ekspeditsii (Proceedings and Research of the Kama-Vyatka Archaeological Expedition) 25. Izhevsk: Udmurt State University, 113-123 (in Russian).

Chernykh, E. M. 2013. In Povolzhskaya arkheologiya (Volga River Region Archaeology) 1 (1), 153-165 (in Russian).

Chernykh, E. M. 2018. In Stratum plus. Archaeology and Cultural Anthropology (3), 267-290 (in Russian). Chernykh, E. M., Vanchikov, V. V., Shatalov, V. A. 2002. Argyzhskoe gorodishche na reke Viatke (Argyzh Hillfort on the Vyatka River). Moscow: Institute of Computer Research (in Russian).

Chernykh, E. M., Kolobova, T. A. 2006. In Rossiiskaia Arkheologiia (Russian Archaeology) (4), 145-151 (in Russian).

Chernykh, E. M., Perevozchikova, S. A., Mutryakov, A. E. 2009. In Lukas, O. G. (comp.) 100 let-eto povod. Materialy nauchno-prakticheskoi konferenrsii "Institute kul'tury: balans traditsiu i novatsiy" (100 Years is a Reason". Proceedings of the Scientific and Practical conference "Institute of Culture: the Balance of Traditions and Innovations"). Sarapul: "Sarapul'skaia tipografiia” Publ., 40-48 (in Russian). 
Chernykh, E. M., Tishchenko, I. G. 2006. In Morozov, V. M. (ed.). Piatye Bersovskie chteniia (Fifth Bers Readings). Yekaterinburg: "Kvadrat" Publ., 125-129 (in Russian).

Chernykh, E. M., Tsyngvitseva, T. A. 2006. In Obydennova, G. T., Savelyev, N. S. (eds.). Iuzhnyi Ural i sopredel'nye territorii v skifo-sarmatskoe vremia (Southern Ural and Adjacent Territories in Scythian and Sarmatian Time). Ufa: "Gilem" Publ., 180-186 (in Russian).

Chikunova, I. Yu. 2002. In Vestnik arkheologii, antropologii i etnografii (Bulletin of Archaeology, Anthropology and Ethnography) (4), 119-126 (in Russian).

\section{About the Author:}

Chernykh Elizaveta M., Candidate of Historical Sciences, Professor. Udmurt State University, Universitetskaya St., 1, Izhevsk, 426034, Udmurt Republic, Russian Federation; emch59@mail.ru

Статья поступила в журнал 01.02.2021 г. Статья принята к публикации 01.02.2021 г. 